\title{
Between Poverty and Energy Satisfaction in Polish Households Run by People Aged 60 and Older
}

\author{
Marlena Piekut \\ College of Economics and Social Sciences, Warsaw University of Technology, Plac Politechniki 1, 00-661 Warsaw, \\ Poland; marlena.piekut@pw.edu.pl
}

check for updates

Citation: Piekut, M. Between Poverty and Energy Satisfaction in Polish Households Run by People Aged 60 and Older. Energies 2021, 14, 6032. https://doi.org/10.3390/en14196032

Academic Editors: Michal

Bernard Pietrzak and

Marta Kuc-Czarnecka

Received: 13 July 2021

Accepted: 17 September 2021

Published: 22 September 2021

Publisher's Note: MDPI stays neutral with regard to jurisdictional claims in published maps and institutional affiliations.

Copyright: (C) 2021 by the author. Licensee MDPI, Basel, Switzerland. This article is an open access article distributed under the terms and conditions of the Creative Commons Attribution (CC BY) license (https:// creativecommons.org/licenses/by/ $4.0 /)$.

\begin{abstract}
The household sector contributes significantly to a country's energy consumption. Energy carrier expenses are the highest expenditures in Polish household budgets. Households run by individuals aged 60 and older are heavily burdened with energy expenditures. The scientific aim of the research is to present and assess housing conditions, with particular emphasis on energy poverty in households run by individuals aged 60 and older. Multivariate statistical analyses were used to conduct the research objectives (cluster methods, variance methods, regression methods). This paper identifies a new index-one that has been applied to the situation in Poland. Households that consist of elderly people are strongly diversified in terms of housing conditions (including energy conditions). There are concerns that some households are not able to access energy services that are required to satisfy basic human needs, particularly individuals with low levels of education, living on social benefits, with low disposable incomes, or living in the countryside. Households represented by men aged 60 and older have better energy supply than households run by women. The older the individual representing the household, the greater the likelihood that his/her energy service needs are not met.
\end{abstract}

Keywords: aging population; elderly; older people; poverty of energy; comfort of energy; consumption; household

\section{Introduction}

The article focuses on energy consumption in households. Household expenditures involve many categories, including consumer goods and services (including food and nonalcoholic beverages, housing maintenance and equipment, educational, and recreational and cultural services); energy carrier expenditures are one of the largest shares of total consumption expenditures (Poland, Germany) [1,2]. The paper examines households run by people aged 60 and older, i.e., the group that is the most burdened with energy expenditures [3,4]. A high share of the above-mentioned expenditures may, in the case of a notable group of households, lead to unmet heat-related needs, which in turn causes energy deprivation and energy poverty [5-7].

The topic (energy consumption in households) considered in this article is important, due to theoretical and practical reasons, taking into account the functioning of the housing market and investor decisions [8,9]. On the theoretical level, it is important to diagnose the housing situations of the elderly and any existing problems [10], both at a national level [11,12] and throughout Europe [13-15]. On the practical level, it is important to find solutions that serve both seniors in their everyday lives (e.g., removing inconveniences in apartments) as well as investors, so that new housing products can meet the actual needs of seniors. Recognizing housing conditions, e.g., ensuring that there is heat in the apartment and finding energy impoverished households, is important, from the point of view from a country's social policies, and in accordance with social policy forecasts $[16,17]$. Energy poverty impacts one's standard of living and health. These issues are important to politicians and other healthcare managers [18-21]. Energy used in households is also a significant problem, particularly concerning responsible consumption [22]. For sectors 
dealing with the modernization of residential buildings - the standard of buildings and the related satisfaction of living conditions is interesting [23-25]. The problem addressed is valid from the point of view of the United Nations sustainable development goals [26,27].

Household energy spending is a global problem, where the globalization process [28-30], especially in the case of EU member states [31-33], has intense influence on convergence tendencies, in terms of the expenditure amounts and the energy carriers used in the households. Systematic development of the globalization process has contributed to the creation of a new institutional order; thus, it is necessary to consider the energy transformation of countries and social consequences [33-36]. The globalization process has led to the emergence of interdependencies between economies, in terms of various socioeconomic aspects [35-40], including those related to household consumption structures [41-43]. They also translate into purely economic aspects, contributing to a higher level of innovation and competitiveness of economies [34,35], which, in turn, increases the level of innovation and competitiveness of these economies [44-48]. Undoubtedly, the globalization process is responsible for economic convergence in a selected group of countries, including EU member states $[49,50]$. Economic convergence affects the structures of households and their main characteristics, mainly related to the increase in wealth or the types of employment of the household members [51-59]. Thus, the globalization process and the ongoing economic convergence of countries have contributed to a permanent change in household approaches to consumption, especially in terms of energy consumption [60-63].

Analyzing selected groups of households is challenging, when considering the ongoing energy transformation of countries, the possibility of using various energy and heat carriers, the possibility of purchasing energy from different suppliers, changing consumer attitudes, and changes in the structures of households. The article analyzed household energy carrier expenditures in Poland. The scientific objective of the research is to present and assess housing conditions, with particular emphasis on energy poverty in households comprised of people aged 60 and older. The paper presents an assessment method applied to Polish households, and a specific target group of residents-individuals aged 60 and older. In particular, this work aims to provide a deep analysis and assessment of housing conditions in Poland, particularly linked to energy poverty, and households run by older individuals.

Poland is an interesting object of analysis due to the growing similarity of Polish consumption patterns with those observed in Western Europe, as well as a specific imitation of consumption patterns pertaining to countries with a higher standard of living [64]. The processes taking place in Poland-as in other countries in Central and Eastern Europe [65] — can be a good prognostic example regarding changes in the behavioral patterns of households in countries with lower standards of living.

This study will be used to evaluate the relationship between the risk of energy poverty and particular sociodemographic/economic features of the household representatives.

Energy is a key area of action in sustainable development. The Agenda for Sustainable Development adopted by the United Nations includes, inter alia, such tasks as ensuring universal access to affordable, reliable, and modern energy services [66]. The household sector contributes significantly to a country's energy consumption, although its share in total consumption decreases each year. In Poland, in 2019, households represented an estimated $26.3 \%$ of final energy consumption; three years prior, it was $30.5 \%$; in 2006 , it was $34.2 \%$ [67].

In 2019, Polish households, on average, spent $10.2 \%$ of their total expenditures on consumer goods and services, in regard to energy carriers (coal, gas, and other fuels). This high value may affect the existence of a significant group of people (i.e., households unable to access energy services required to satisfy basic human needs) and may undoubtedly lead to energy deprivation and poverty. The literature review $[10,68-70]$ and the statistical analysis [71] indicate that households comprised of individuals 60 and older are the groups overloaded with energy carrier costs. In Poland in 2018, expenditures on energy, gas, and other fuels consumed $11 \%$ of disposable income (used interchangeably with available 
income) of a 60 and older household, while in households with younger persons, it was $6.0-8.1 \%$ of their disposable income (Figure 1 ).

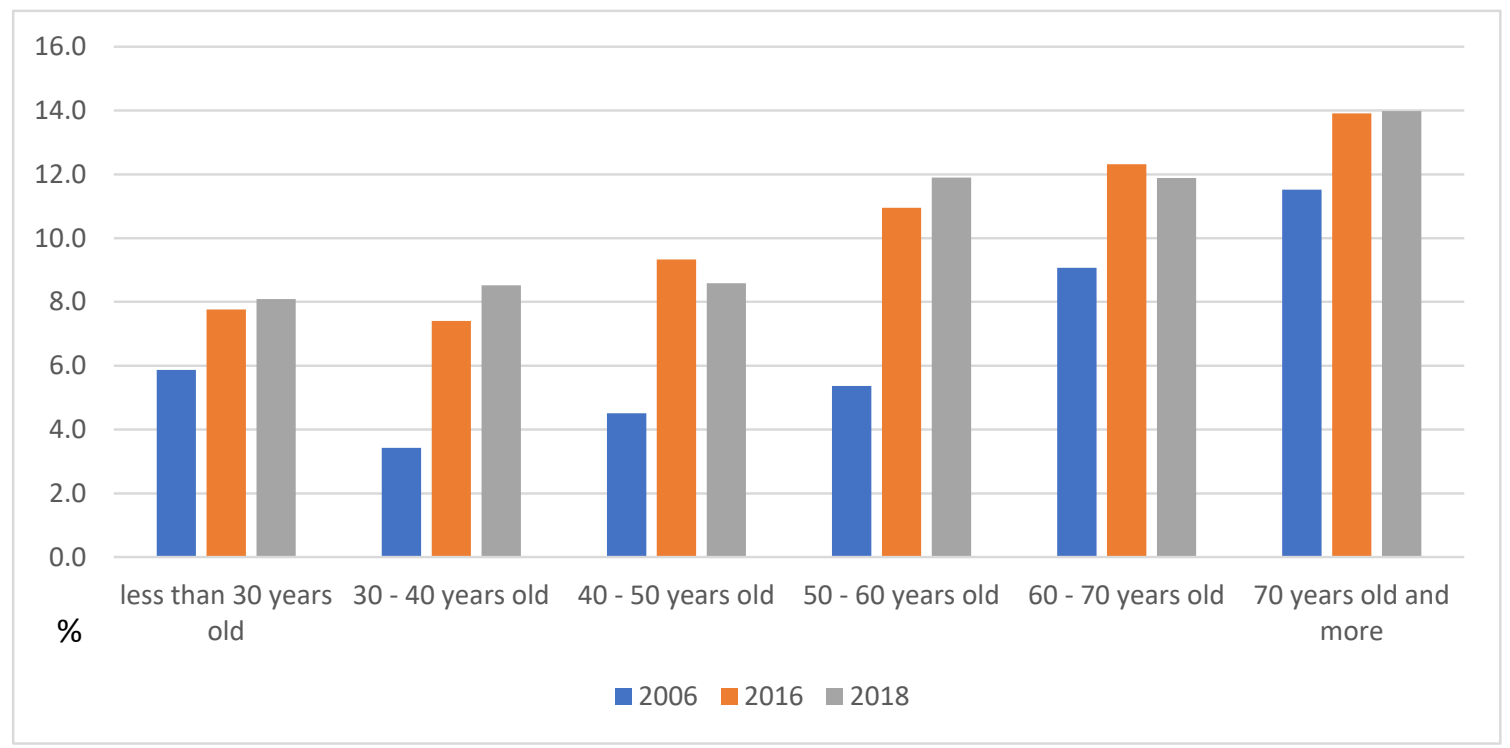

Figure 1. Share of energy expenditure in disposable income in households by age of the person running the household in Poland in 2006, 2016, and 2018. Source: own elaboration based on data from [72-74].

The number of 60 and older households is continuously increasing, in both relative and absolute values, and this trend is projected [71] to grow. For the purpose of the described research, the expression "energy poverty" is explained as the scarcity of affordable energy and lack of satisfaction of household energy necessities. It is worth noting that the smaller possibility of getting economically viable energy is related to a higher share of energy expenses (over 20\%) in available income [1]. The paper deals with the issues of energy poverty among the elderly, but it should be kept in mind that energy poverty has wider boundaries, and is not simply associated to a targeted age range.

\section{Literature Review}

\subsection{Housing Conditions and Their Roles in the Lives of Older People}

In the scientific literature, issues related to old age receive a lot of attention, mainly due to the increase of aging societies. The above-mentioned issue, of aging societies, affects Poland as well. The size of the population in the 60 years and older age group is characterized by the highest growth dynamics. In Poland, in the 1990s, this group accounted for about $15 \%$ of the entire population; in the second decade of the 21 st century, the number was estimated at more than 20\%. According to forecasts, in 2035, elderly people will constitute over $28 \%$, and in 2050 -over $40 \%$ of the entire Polish society [55]. Longevity, i.e., extending the duration of human life, is—on the one hand-perceived as a civilization achievement, and on the other hand, it generates a number of challenges in the economic, social, and cultural spheres. The housing infrastructure problem is not adapted to the needs of older people, which constitutes a major challenge. In particular, this concerns the needs related to the shaping of the broadly understood housing conditions, which have a significant impact on the quality of life of older people [75-77].

Housing conditions are one of the indicators related to quality of life-understood as an objective assessment related to satisfying human needs [78]. Meeting housing needs, i.e., housing standards depends on the technical conditions of the building or flat (standard of goods, construction standards), as well as the manner of use and the population (standard of use). The first one determines the level of satisfaction of needs in relation to the usable space, interior finishing, and furnishing of a building or apartment [79]. The second one is 
associated with the number of people per flat or room and the average floor space per flat, household, or person.

The above-mentioned, alongside the ages of the individuals in the home, and their progressing disabilities, it may turn out that the current flat has many architectural barriers or does not meet the other needs of older people (e.g., it is too large). In such a case, it is important to help elderly people adapt to changing conditions so that they maintain their wellbeing and independence in their daily activities longer [80]. It is also important that older people have the right to choose their residences freely and that they have the option to live in their flats for as long as possible. This is reflected in many international documents, including in the Vienna International Plan of Action on Aging, adopted in 1982 by the World Assembly on Aging, and in the UN Principles for Older Persons, adopted in 1991. The directives and resolutions define the rights of seniors in relation to, inter alia, choosing the form of residence and receiving support, enabling implementation of this entitlement. The above-mentioned (and other rights) surround the principles of independence, participation, care, self-fulfillment, and dignity. In addition, the Revised European Social Charter (Article 23) indicates the need to let the elderly freely choose their way of life, and to live independently in a familiar environment for as long as they wish (and are capable to do so), as one of the guiding principles for full participation in society. The implementation of this right should be executed, inter alia, by providing housing adapted to the needs of older people and their health conditions, and by providing appropriate assistance in adapting housing to their needs.

Housing conditions that are in the comfort zone can positively affect the health and well-being of aging individuals [81]. Simultaneously, conditions that extend beyond the comfort zone are known to cause a number of health complications, as the elderly tend to be more vulnerable to the inconvenience of a home environment [82]. The comfort zone includes, among others, ensures proper temperature in the living quarters. "Thermal comfort" is defined by the American Society of Heating, Refrigerating, and Air-Conditioning Engineers (ASHRAE) as "the state of mind which ex-presses satisfaction with the thermal environment" [83]. For every individual, the home is the basic point of reference. For older people, it is of particular importance, as it is a place where most needs are met. Reduced physical and mental capacity, increased limitations resulting from disabilities, difficulties, in terms of spatial mobility, and a sense of threat to public safety, mean that older people spend more time in their lodgings and their immediate vicinities. Therefore, an important issue in this context is whether the dwellings occupied by older people meet their needs, providing conditions that make it possible for them to live independent and dignified lives. When considering the housing situation of older people, two crucial aspects should be focused on. The first is objective housing conditions, measured with the use of indicators, such as the area of the flat, the standard of the flat, the amount of expenditure on energy carriers. Qualitative, non-measurable aspects also play a significant role, and they are frequently more important for older people than the quantitative aspects described above. They include, among others, the level of satisfaction with meeting the needs, for example, thermal conditions in the apartment.

The standard of the apartment, as well as its amenities, are the main factors that influence housing satisfaction and overall life satisfaction. In a recent study examining the situation of the elderly in Vietnam [25], it was shown that housing satisfaction has a strong positive effect on life satisfaction. Housing is an important area of life and, therefore, housing satisfaction is a strong predictor rating for life satisfaction and the quality of life. People invest their resources in their homes and their welfare increases as a result. Policies and programs to help poor families and improve housing facilities can improve the quality of life of poor, elderly people [25]. Taking effective actions to improve the housing conditions of the elderly requires, first, knowledge on how they live and how they evaluate their housing situations.

Zrałek [84] points to the improvement of the housing conditions of elderly people in Poland, as evidenced by, inter alia, the indicators characterizing the degree of the housing 
population. Households of retirees have the largest usable floor space per person $\left(35.1 \mathrm{~m}^{2}\right)$, while the average floor area of a flat in Poland is $25.4 \mathrm{~m}^{2}$ per person. This is due to changes of the compositions of households of older people-children leaving their family homes or widowhood. Although the population norm, applicable at the time of the settlement of the apartment, was designed for two-generation families, and was characterized by a relatively small area, due to the current size of households of elderly people, these apartments provide larger areas per person. In general, the older the head of a one-person household is, the less often the apartment is overcrowded. In the case of multi-person households with an elderly person as the head of the household, the situation is much less favorable, as almost $30 \%$ of these households live in densely populated apartments [84].

It is also indicated that the elderly, living in small households or alone, live in flats that are too large and too expensive [1], which they do not want or cannot leave. An objective factor limiting the possibility of switching flats is the limited supply of small flats. Such flats are very popular because they are attractive to young people due to their price, but often too expensive in relation to the financial possibilities of old people [84]. The research findings show that the elderly are passive when it comes to modernizing their apartments [85]. Seniors, regardless of their living conditions, rarely decide to replace their current apartments with smaller ones, which may be cheaper to maintain and more modern. Among seniors, the attachment to the housing environment appears very strong [86]. This fact is indicated not only by studies carried out in Poland, but also by research conducted in Germany [87], Hong Kong [88], Ireland [89], Spain [90], and the Netherlands [91].

Another problem related to the housing conditions of older people is energy poverty. In Poland, it particularly affects the elderly in large houses in the countryside [1,92].

\subsection{Influence of Demographic and Socioeconomic Determinants of Elderly People on Housing Conditions and Satisfaction with Housing}

Providing appropriate housing conditions, including thermal comfort and satisfaction, is related to the financial situation of the household [1]. Households with a lower affluence ratio are more likely to suffer from energy poverty because their income cannot cover their energy expenditure. Households that inhabit individuals with low wages or benefits are unable to spend more to access the right amount of energy [93]. Insufficient amounts allocated to housing, including heating, lead to lower satisfaction with housing conditions. Research shows that people in higher-income households are generally more satisfied with housing, have more financial resources to live in better homes, and could afford better interior furnishings. Thus, higher income has a positive effect on respondent satisfaction with housing [94-99], although there are reports showing that income has a negative impact [100] or does not have a significant impact on satisfaction with housing conditions [101]. The latter is caused by the fact that people with higher incomes tend to aspire higher, compared to their current housing standards, which in turn may reduce their satisfaction with housing $[25,102,103]$.

Age is another factor that influences living conditions. For example, elderly people prefer different thermal conditions than younger people [104-109], although there are studies that show no differences between older and younger people in this respect [110-114]. One may observe that, in everyday life, the elderly may be less active; therefore, they prefer higher ambient temperatures [112]. Age is important, not only in terms of the subjective perception of satisfaction with housing conditions, but it also constitutes an important determinant of multidimensional energy poverty. Moreover, it has emerged that senior age increased energy sensitivity [93].

Analyzing the role of gender, some researchers indicated that women are more satisfied with their homes than men [1,96,115], while other studies [99,100,116-118] did not show the influence of gender on satisfaction with housing. However, in relation to elderly people, the research findings have indicated that gender plays a significant role in the perception of the thermal environment. The thermal conditions preferred by the elderly and women differed from those preferred by younger adults and men. Women were more sensitive to cold and deviations from individual optimal conditions than men. Moreover, 
women often preferred higher temperatures [119-122]. Households with a woman as the main breadwinner were also at a higher risk of multi-dimensional energy poverty. In this context, it is important to emphasize that there is a gender imbalance in employment opportunities and the level of remuneration. Women generally receive lower wages than men, which negatively affects the living conditions in their households [93].

It was also found that education is an important determinant of housing satisfaction. However, the impact of education on satisfaction with housing tends to be perceived as ambiguous. The relationship between education and housing satisfaction was found to be positive in Taiwan [123] and China [124], but negative in Ghana [125]. Moreover, studies [126] revealed that, although the level of education contributed significantly to the housing satisfaction of Asians, there was no correlation in the case of white individuals. Regarding thermal comfort, previous studies [1] showed that the level of education is a very important determinant among those who run the households. People with higher education were less likely to experience energy poverty, and their needs, in terms of thermal comfort, were satisfied to a higher degree. However, in the case of some older people, apart from the favorable objective characteristics of their households (the level of disposable income, the share of energy expenditure in disposable income, the technical and sanitary condition of buildings), problems occurred with fully satisfying energy-related needs (in subjective terms). This may be related to the higher aspirations of more educated individuals.

Another feature related to housing conditions and satisfaction is the number of people in the household. The larger the household, the more dissatisfied with the housing conditions individuals tend to be $[94,123,127,128]$. Compared to smaller families, larger families were also more prone to suffer from energy poverty [93].

Health status is another factor that significantly influences housing satisfaction. The better the health of the individuals, the more satisfied with the housing conditions they tend to be [95]. The literature on the subject also shows that the level of housing satisfaction is mainly determined by a number of physical characteristics of the residential and neighborly environment [94,100,125,129-133]. Larger apartment sizes, better internal structure of the apartment, type of housing (better homes), location, and surroundings of the apartment building were positively associated with housing satisfaction. Moreover, many studies have found a positive relationship between the length of stay in a given place and housing satisfaction $[100,127,134]$, while other studies have shown the negative effects of such circumstances [135]. It was also noted [93] that multi-dimensional energy poverty was more common in rented housing than in the dwellings owned by household members.

To summarize, the size of the house, homeownership status, place of residence, household financial situation, age, gender, education, occupation, and marital status of the head of the household, as well as the size of the household, were significant determinants of energy poverty in households. It was noticed that, in most cases, these features were both overlapping and interdependent. Therefore, when studying the influence of specific features on examined phenomena, their multidimensional relationship should be taken into account. All the accumulated assets or earnings determine the nature of employment, which in turn determines the level of education. No single socioeconomic variable causes or determines multidimensional energy poverty; it is a combination of many of these variables leading to a specific outcome $[1,93]$.

\section{Methods of the Research}

\subsection{Data Sources and Study Design}

The research concerns Polish households with people aged 60 and older. The research material was from Statistics Poland data. The data covered 36,000 to 37,000 cases (households). There were 10,114 (27.0\% of all respondents) in $2006,13,859$ (37.8\%) in 2016, and $14,461(40.0 \%)$ in 2018, regarding households of people aged 60 and older [136].

Implementing the research goal required examining the following research problems:

- $\quad$ Constructing an aggregate index of energy poverty; 
- Identifying the types of households run by people aged 60 and older who were at risk of energy poverty;

- Distinguishing the types of households of people 60 and older, according to the characteristics describing the expenses needed to maintain a flat, as well as housing conditions.

The following research procedure was adopted.

Research task no. 1. The author designed an aggregate indicator as a measure to identify the types of households run by people aged 60 and older, considering their exposure to energy poverty. The created indicator was verified by analyzing the correlation between its components. The aggregate indicator was created based on the concept presented in the author's earlier work [1], but it was adapted to the needs of the study presented in this paper and the statistical data available. The decision to build an aggregate index was supported by an analysis of the literature on energy poverty [137-144].

The aggregate indicator consisted of two components, i.e., (a) the component describing the objective housing situation of older people (their housing conditions), and (b) the component describing their subjective satisfaction with their apartment/home.

Undoubtedly, energy poverty-apart from the fact that it concerns the energy circumstances of households - is strongly associated with poverty construed economically as deprivation of access to material goods and resources. Therefore, the components of the aggregate index of energy poverty include such variables as the financial situation of a household and the level of satisfaction of the primary needs of their members, such as food.

Research task no. 2. For the delimitation of households of people aged 60 and older, the following steps were adopted:

1. Applied the k-means cluster analysis with the application of data mining techniques. K-means cluster is described, among others, in the books: L. Kaufman, P. Rousseeuw [145], and A. Kassambara [146], and in papers [147-149]. Clustering is a process of partitioning a set of data objects from one set into multiple classes. Finding groups (clusters) in the data was the aim of the analysis. Data points are clustered based on feature similarity [150].

2. Calculated the average values for each cluster using the arithmetic mean (e.g., expenditure on energy, gas, and other fuels), horizontal distributions of socioeconomic and demographic features for each cluster (e.g., gender).

3. Compared the differences in mean values of the parameters associated to energy carriers between the clusters using the analysis of variance and post hoc tests (the Tukey's range test (HSD) or Scheffe test [151]). The alpha level of 0.05 was used in the article.

\subsection{Test Method and Preliminary Research Results}

In order to achieve research objective no. 1, the author used an aggregated indicator that was adapted to this research, and took into account variables related to energy expenses, the degree of satisfaction of the needs related to using energy carriers, and the standard of a flat or a house (Table 1). It is worth mentioning that the building characteristics may have a strong influence in addition to income status and the other parameters considered. The role of the building system (construction quality and level of efficiency) is quite relevant in concurring to fall in energy poverty [152-154]. However, it is not fully translated into the investigated variables within the adopted methodology.

The division into groups of households, according to the share of expenditure on energy carriers (less than 10\%, 10-20\%, and above 20\%), results from the adopted thresholds described in the literature. According to the first official British definition from 1991, created by B. Boardman, and applied by researchers and practitioners in other countries, it is assumed that "a household is fuel poor if it has to spend more than $10 \%$ of its income on fuel to maintain an adequate level of heat" [155]. 
Table 1. Aggregate index of energy poverty (thermal comfort) for households of people aged 60 and older in Poland.

\begin{tabular}{|c|c|c|}
\hline Variables & Possible Answers and Evaluative Loads & Maximum Number of Points in 2018 \\
\hline \multicolumn{3}{|l|}{ Objective variables } \\
\hline $\begin{array}{c}\text { Share of expenses on energy carriers in } \\
\text { disposable income }(\%)\end{array}$ & $\begin{array}{l}\text { Less than } 10 \%-2 ; 10 \% \text { to } 20 \%-1 \text {; Above } \\
\qquad 20 \%-0\end{array}$ & 2 \\
\hline Access to hot running water & Yes- $1 ; \mathrm{No}-0$ & 1 \\
\hline The period of construction of the building & $\begin{array}{l}\text { Until } 1960-0 \text {; in the years } 1961-1995-1 \text {; } \\
\text { in the years 1996-2011-2; after 2011-3. }\end{array}$ & 3 \\
\hline $\begin{array}{l}\text { Leaking roof, damp walls, floors, rotting } \\
\text { windows or floors }\end{array}$ & Yes- $1 ; \mathrm{No}-0$ & 1 \\
\hline $\begin{array}{l}\text { The amount of expenditures associated } \\
\text { with maintaining the apartment above } \\
\text { the subsistence level ( } 340 \text { PLN) }\end{array}$ & Yes- $1 ; \mathrm{No}-0$ & 1 \\
\hline $\begin{array}{l}\text { The level of disposable income by } \\
\text { quintile groups }\end{array}$ & $\begin{array}{l}\text { 1st quintile group }-1 ; 2 \text { nd quintile } \\
\text { group }-2 ; \ldots ; 4 \text { th quintile group }-4\end{array}$ & 4 \\
\hline \multicolumn{3}{|l|}{ Subjective variables } \\
\hline The flat is cool enough in summer & Yes- $1 ;$ No- -0 & \\
\hline The flat is warm enough in winter & Yes $-1 ; \mathrm{No}-0$ & 1 \\
\hline \multicolumn{3}{|l|}{ Assessment of meeting the needs of: } \\
\hline $\begin{array}{ll}\text { - } & \text { Food; } \\
\text { - } & \text { Timely payment of housing fees; } \\
\text { - } & \text { Healthcare. }\end{array}$ & $\begin{array}{l}\text { Good-4; Rather good-3; On } \\
\text { average-2; Rather bad-1; Very bad-0 }\end{array}$ & 12 \\
\hline
\end{tabular}

To design the indicator, the variables were transformed so that they were all stimulants (larger values of a given variable associated with a more advantageous comfort of energy). The details are described in paper [1]. The values of the descriptive statistics of the aggregate indicators for households of people aged 60 and older are presented in Table 2.

Table 2. The values of descriptive statistics of the aggregate index for households of people aged 60 and older.

\begin{tabular}{cc}
\hline Specification & Indicator Values \\
\hline Means & 20.2 \\
Median & 20.0 \\
Standard deviation & 3.44 \\
Modal & 22.0 \\
Kurtosis & -0.05 \\
Minimum & 4.0 \\
Maximum & 29.0 \\
The first decile & 18.0 \\
The ninth decile & 23.0 \\
Coefficient of variation & 17.0 \\
Coefficient of asymmetry & -0.42 \\
\hline
\end{tabular}

Source: own elaboration based on data from [136].

The distribution of the aggregate indicator turned out to be similar to the normal distribution, although the Lilliefors distribution normality test formally rejected the normality hypothesis. The distribution of the index was characterized by a slight left-hand asymmetry (a slightly larger number of households are above the average) (Figure 2).

\subsection{Types of Households according to Housing Conditions and Apartment Satisfaction}

Research task no. 2. To identify clusters of households, the author used cluster analysis (k-means method) with the application of data mining techniques. The V-fold cross-validation test used the selection of the optimal number of groups (number of trials10). The optimal number of clusters was assumed to be 5, according to the diagram titled "Cost sequence chart" (Figure 3). 


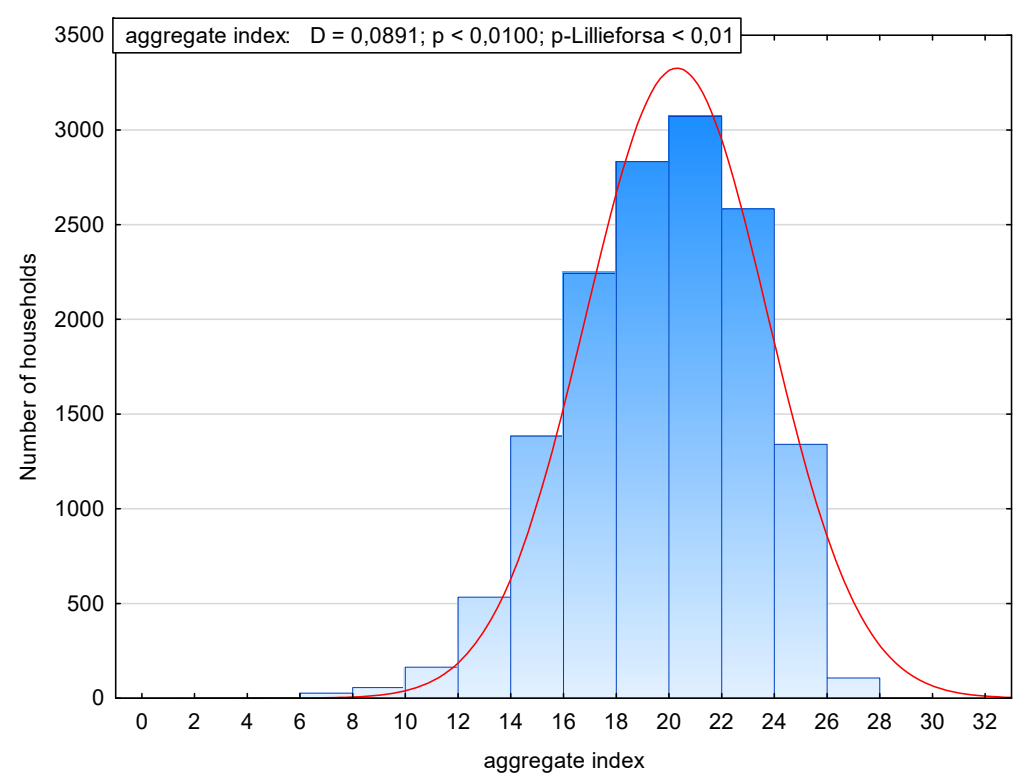

Figure 2. Distribution of the aggregate indicator for households of people aged 60 and older in 2018. Source: own elaboration based on data from [136].

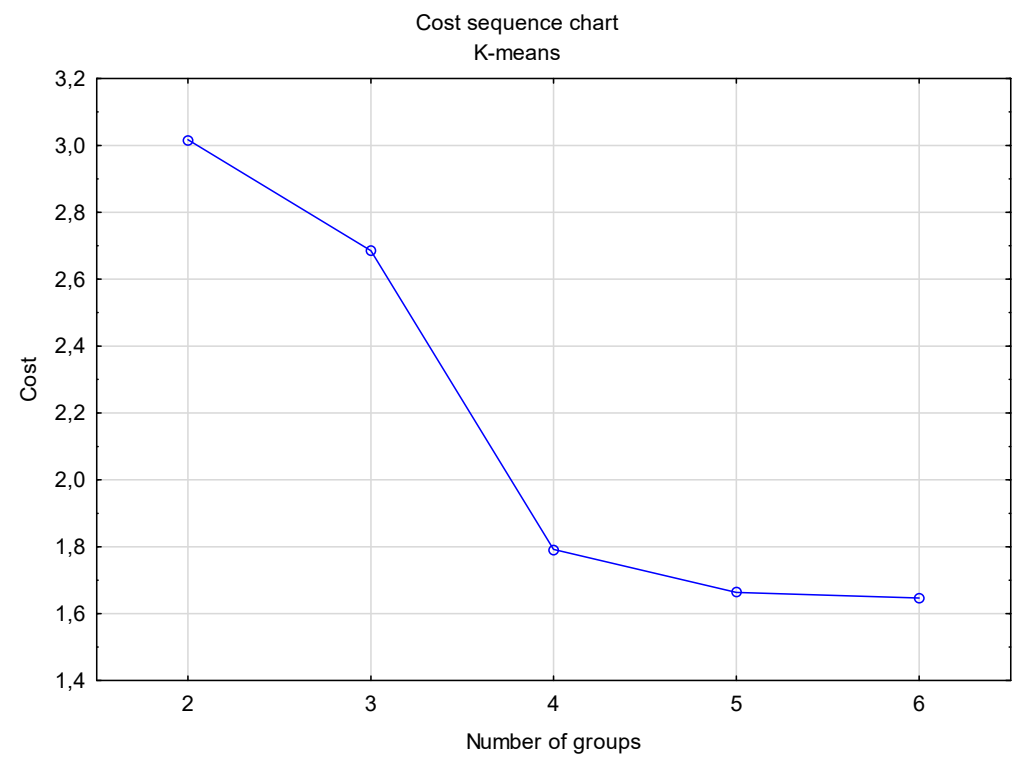

Figure 3. Cost sequence chart for k-means classification for households of people aged 60 and older in 2018. Source: own elaboration based on data from [136].

\section{Results}

4.1. Housing Conditions in Polish Households of People Aged 60 and Older, and Younger, in 2006, 2016, and 2018

Housing conditions positively affect the health and well-being of individuals. When analysts compare the conditions related to access energy carriers in households of people up to 60 years of age, and over 60 years of age, the conditions of the younger age group tend to be assessed as better. A larger percentage of households of people aged 60 and older (in 2018 - the level was estimated at about 14\%) compared to younger ones (less than $13 \%$ ) reported problems connected with not meeting the needs related to maintaining the proper temperatures in the living spaces.

Together, with the transition to the next age group, a higher percentage of households had a higher share of expenses in energy, gas, and other fuels in their available income. In 2018 , the share of households of people up to 60 years of age, in which $10 \%$ or more of their 
disposable income was spent on energy carriers, amounted to about $22 \%$, while in the case of households of people over 60, depending on the age group, the percentage ranged from 38 to $46 \%$.

A larger percentage of elderly households were also equipped with solid fuel stoves, e.g., coal-fired stoves, which are less convenient than central heating. In the case of younger people, about $10 \%$ of households were equipped with such stoves, while among the households of older people-the share was estimated at 12-16\%.

By comparing the changes, which took place over time, it should be noted that the conditions with regard to energy carriers in households of the elderly improved. In the years 2006-2018, the percentage of households with a high, i.e., $20 \%$ and more, share of expenses of energy, gas, and other fuels, of available income, decreased. For example, in households of people aged 60-70, this percentage decreased by $9.2 \mathrm{pp}$ (percentage points) and in the oldest age group, i.e., 80 years and more-by $10.2 \mathrm{pp}$. The share of households equipped with a solid fuel-fired furnace also decreased. In the case of people aged 60-70, this percentage decreased by $6.9 \mathrm{pp}$, and in the case of people aged 80 and older, by $19.9 \mathrm{pp}$. Regarding thermal comfort in a flat, the lack of statistical data for 2006 made it impossible to carry out a comparative analysis of this feature in examined households. However, it was noticed that in the years 2016-2018, the percentage of households with problems regarding thermal comfort in the apartment decreased slightly, albeit more in the case of households of younger people, up to 60 years of age, than in those of older people (Table 3).

Table 3. Comparison of conditions in terms of energy carriers in households by age of the person running the household in 2006, 2016 and 2018.

\begin{tabular}{|c|c|c|c|c|c|}
\hline Household Characteristics & Year & $\begin{array}{l}\text { People under } \\
60 \text { Years of Age }\end{array}$ & $\begin{array}{l}\text { People Age } \\
60-70\end{array}$ & $\begin{array}{c}\text { People Age } \\
70-80\end{array}$ & $\begin{array}{l}\text { People Aged } \\
80 \text { and Over }\end{array}$ \\
\hline \multirow{2}{*}{$\begin{array}{l}\text { Unfulfilled needs related to thermal comfort in } \\
\text { the apartment (warm in winter, cool in summer) } \\
\text { (\% households) }\end{array}$} & 2016 & 17.4 & 15.8 & 15.7 & 14.8 \\
\hline & 2018 & 12.7 & 14.0 & 13.5 & 14.6 \\
\hline Changes in percentage points & & -4.7 & -1.8 & -2.2 & -0.2 \\
\hline \multirow{3}{*}{$\begin{array}{c}\text { Share of expenditure on energy carriers in } \\
\text { disposable income above } 20 \% \\
\text { (\% households) }\end{array}$} & 2006 & 13.4 & 19.8 & 22.3 & 24.0 \\
\hline & 2016 & 8.3 & 14.3 & 14.9 & 15.7 \\
\hline & 2018 & 6.2 & 10.6 & 12.0 & 13.8 \\
\hline Changes in percentage points & & -7.2 & -9.2 & -10.3 & -10.2 \\
\hline \multirow{3}{*}{$\begin{array}{c}\text { Share of expenditure on energy carriers in } \\
\text { disposable income between } 10 \text { and } 20 \% \\
\text { (\% households) }\end{array}$} & 2006 & 27.9 & 31.4 & 31.4 & 26.9 \\
\hline & 2016 & 19.9 & 29.1 & 33.9 & 33.2 \\
\hline & 2018 & 15.6 & 27.0 & 32.1 & 32.0 \\
\hline Changes in percentage points & & -12.3 & -4.4 & 0.7 & 5.1 \\
\hline \multirow{3}{*}{$\begin{array}{l}\text { The apartment is heated with a solid fuel stove, } \\
\qquad \begin{array}{l}\text { e.g., coal, wood } \\
(\% \text { households })\end{array}\end{array}$} & 2006 & 17.1 & 18.8 & 25.7 & 35.6 \\
\hline & 2016 & 8.8 & 10.3 & 10.9 & 14.8 \\
\hline & 2018 & 9.9 & 11.9 & 11.8 & 15.7 \\
\hline Changes in percentage points & & -7.2 & -6.9 & -13.9 & -19.9 \\
\hline
\end{tabular}

Source: own elaboration based on data from [136].

\subsection{Economic and Sociodemographic Factors Influencing Energy Conditions in Households of the Elderly}

Housing conditions, including appropriate conditions related to heat and electricity, are determined by many characteristics of households and the technical conditions of their flats. Age is a factor that significantly differentiates the level of the energy poverty index in Polish households maintained by people aged 60 and older. The conducted analysis revealed that the situations of people aged 60 and older, related to providing the abovementioned housing conditions, was worse, compared to younger people, and it was the 
case of a statistically significant difference $(p<0.005)$. The aggregate index in households of people up to 60 years of age was the highest and amounted to 21.1, while in households of people aged 60-70, it was estimated at 20.4, and it decreased with age, reaching 19.8 in the case of households run by people aged 80 and older (Figure 4). However, in the last two age groups, i.e., $70-80$ and 80 and older, no statistically significant differences were found in the level of the aggregate index of energy poverty.

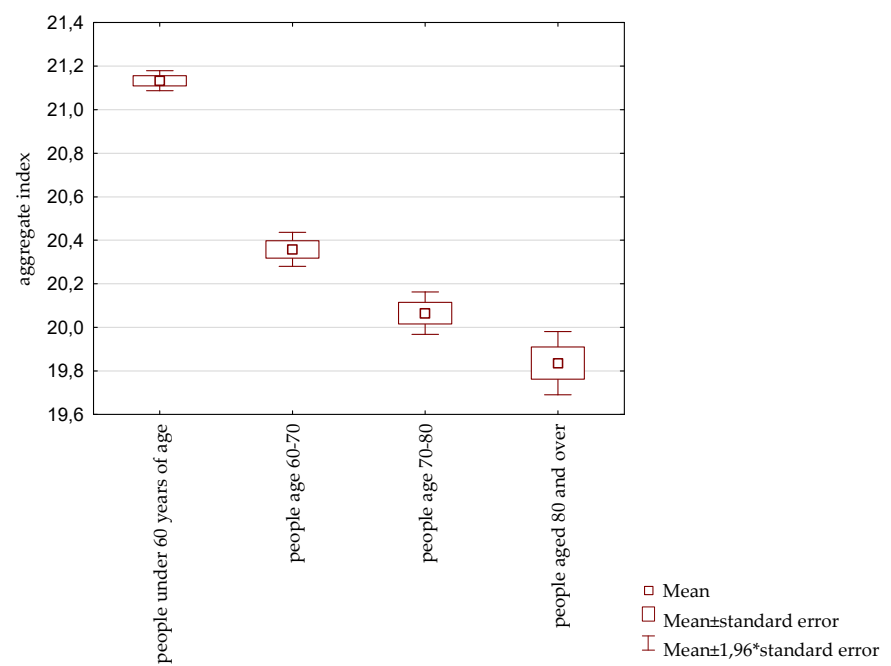

Figure 4. The level of the aggregate indicator in 2018 by age of the person running the household. Source: own elaboration based on data from [136].

The level of the aggregate index of energy poverty depends on the available income level. Thus, for the poorest households, this level is significantly higher $(p<0.05)$ in statistical terms than for households with higher income. In 2018, for $25 \%$ of the 60 and older households forming the first income group (the poorest), the level of the aggregate index was 16.8, whereas for other income groups, it ranged between 18.9 and 23.5 (Figure 5). The mean of the aggregate indicator increased with the higher income groups, the aggregate ratio increased from 2.1 to 2.5 . The income situation is inherently associated with energy affordability. In the group of poorest households, this situation tends to improve, but, unfortunately, this improvement is the slowest.

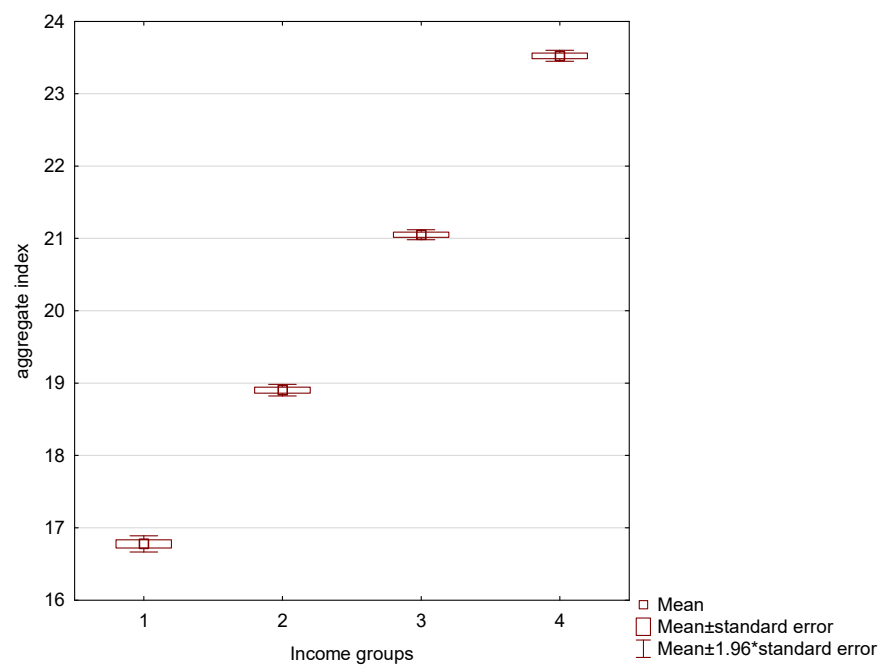

Figure 5. The level of the aggregate indicator in 2018 by income groups for households of people aged 60 and older Comment: the groups of households were divided into four equal groups. In the first quintile group, there were $1 / 4$ of households with the lowest levels of disposable income. Source: own elaboration based on data from [136]. 
The household location is a determinant that significantly differentiates the value of the aggregate index in households of people over 60 years of age $(p=0.0000)$. The research made it possible to distinguish three groups of households of older people, with a statistically significant difference between them, due to the level of the analyzed indicator. The first group with the highest indicator covered households located in cities with over 100,000 inhabitants, the second group represented by households from cities with over 20,000 up to 99,000 inhabitants, and a third covering rural households. The highest index was characteristic for households located in the largest cities, i.e., 100,000 and more inhabitants (20.9-21.3), and the lowest for rural residents (19.4). A graphical presentation of the distributions of the aggregate indicator values, according to the household location, in households of people 60 and older in 2018, is shown in Figure 6.

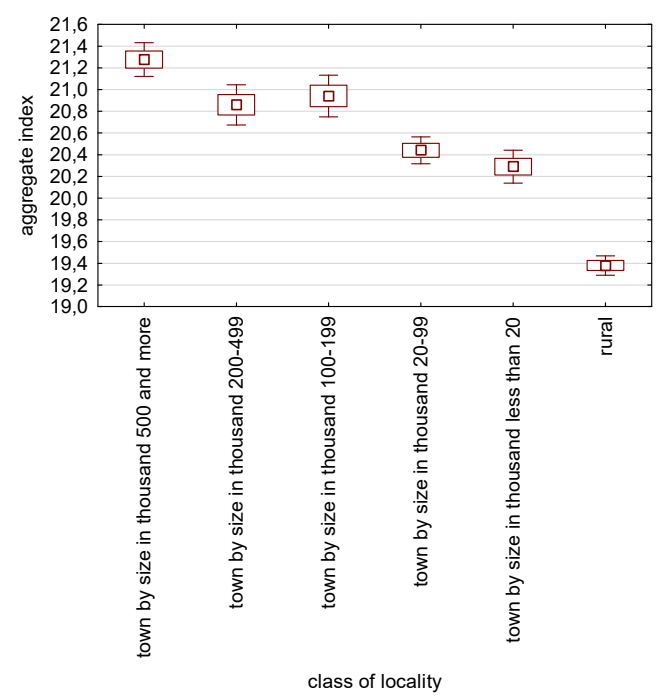

$\square$ Mean \pm standard error

I Mean $\pm 1.96^{*}$ standard error

Figure 6. The level of the aggregate indicator in 2018 by household location for households of people aged 60 and older. Source: own elaboration based on data from [136].

Based on the analysis of the values of the aggregate index, depending on the number of people in the household, it can be concluded that there is one category of a household that is statistically different from the others $(p<0.05)$. The best situation was recorded in the case of two-person households and this category had a statistically significantly higher level of the aggregate indicator than the other categories of households. The value of the analyzed index was 20.7 in the case of two-person households and 19.3-19.9 in other households (Figure 7).

The results also showed that women running households of people aged 60 and older (20.7) had lower thermal comfort than men (19.6). A graphical presentation of the distributions of the aggregate indicator values, according to the sex of the person representing the household of people aged 60 and older in 2018, is shown in Figure 8.

The level of education clearly affects the average level of the aggregate indicator in households of people aged 60 and older, and this correlation appears statistically significant $(p<0.05)$. The mean of the aggregate indicator increased with the higher education level, and the highest increase (by 1.0 percentage point) was observed when moving from secondary to higher level education, i.e., from 20.8 to 22.6. The value of the aggregate index of energy poverty for people with lower secondary and primary education was established at 18.1, while for people with basic vocational education, it amounted to 19.8 (Figure 9).

When considering the aggregate index according to socioeconomic groups, it was noticed that the highest value was recorded for households of non-manual workers and self-employed persons (22.8. and 22.6) and these values were statistically significantly higher than the other indicators $(p<0.05)$. In households referred to as "other", including households of people over 59 years of age, living on social benefits, other than pensions or retirement pays, and other non-profit-making sources of income, the average value of the 
aggregate indicator was estimated at 16.5. Farmers' households (20.1) recorded levels of the aggregate index that were similar to the households of blue-collar workers (20.2) and retirees (20.2) (Figure 10).

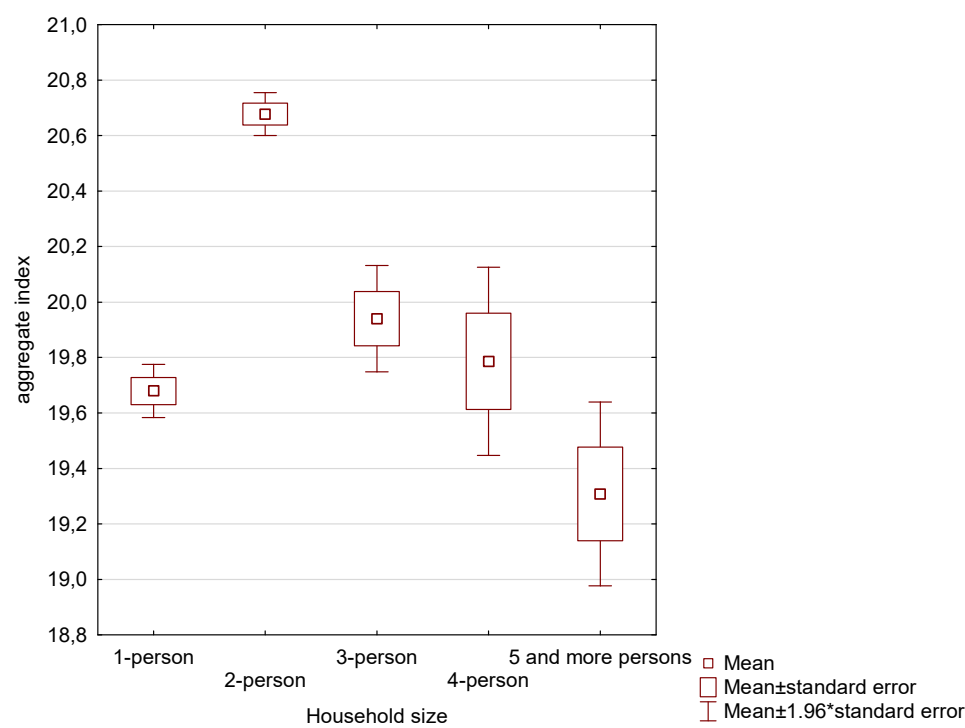

Figure 7. The level of the aggregate indicator in 2018 by household size for households of people aged 60 and older. Source: own elaboration based on data from [136].

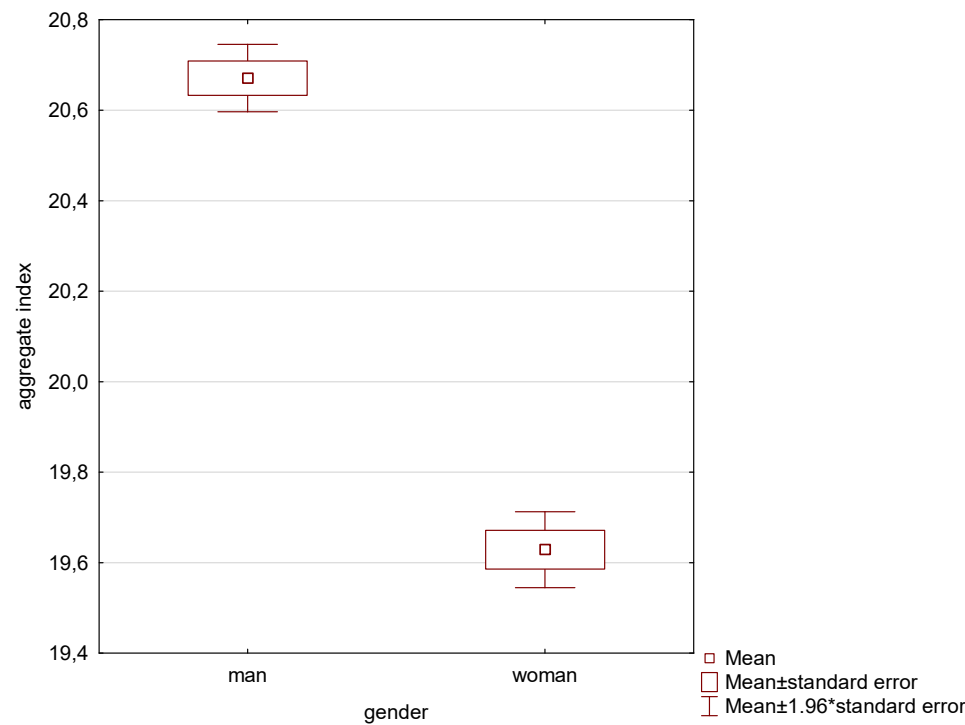

Figure 8. The level of the aggregate indicator in 2018 by sex of the person representing the household of people aged 60 and older. Source: own elaboration based on data from [136].

The marital status of a person running a household is another variable that appears to be statistically significant when differentiating the level of the aggregate indicator $(p<0.05)$. The highest analyzed index was recorded in households of married persons (20.9), and the lowest among people who were never married (19.0). The latter category of households was distinguished by a statistically significantly higher level of the analyzed index among other household categories (Figure 11). 


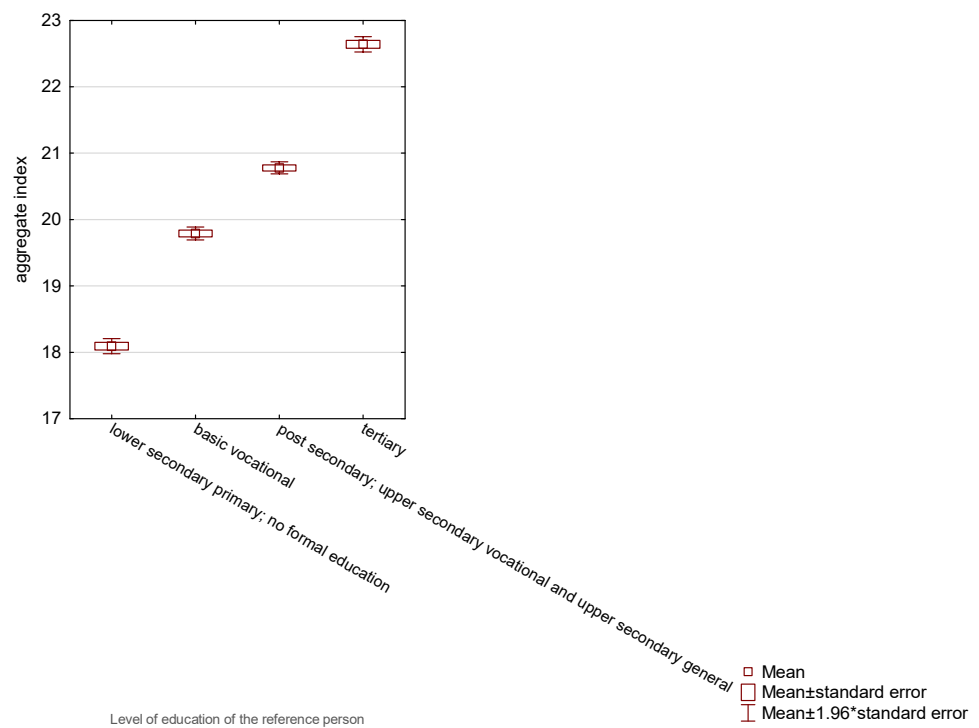

Figure 9. The level of the aggregate indicator in 2018 according to the education level of the person representing the household of people aged 60 and older. Source: own elaboration based on data from [136].

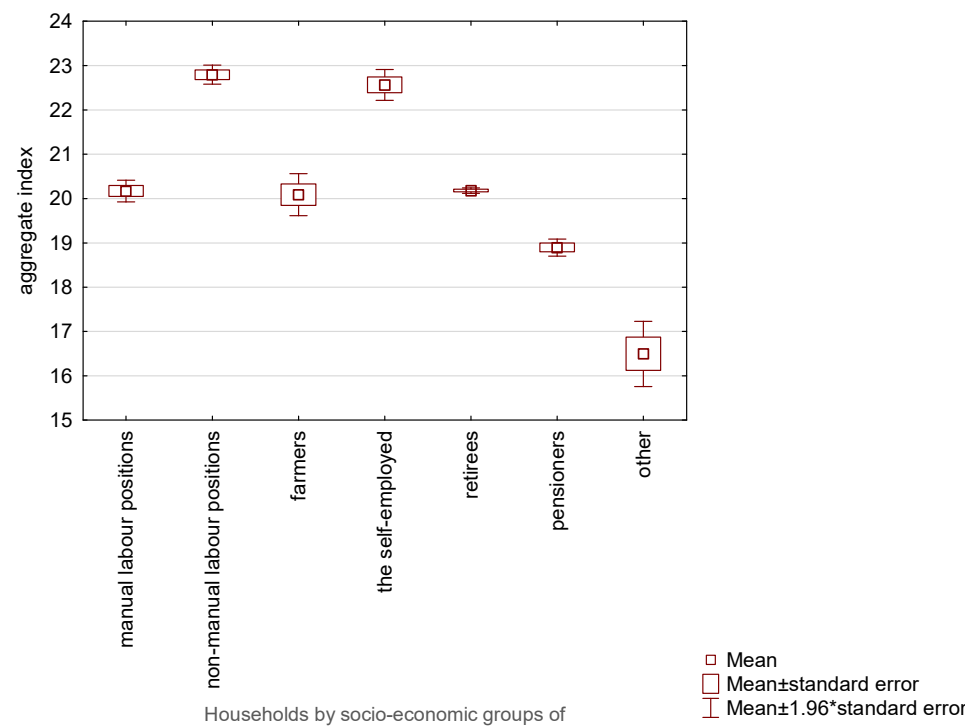

Figure 10. The level of the aggregate indicator in 2018 according to the socioeconomic group of households of people aged 60 and older. Source: own elaboration based on data from [136].

Interesting results were also obtained when comparing the value of the aggregate index depending on the method of heating a house/flat. People whose houses/flats were equipped with central heating (20.5), or which were heated with an electric, gas, or tiled stove with a heater (20.4), indicated the greatest energy comfort. The lowest values of the aggregate index were found in households heated with, e.g., coal, oil, or wood heating stoves (17.4), and only these households differed statistically from the others in terms of the level of the analyzed index. On the other hand, households of older people, where the rooms were heated in a different way, i.e., with portable oil stoves or blowers, showed a large variation in the energy poverty index, and its average value amounted to 19.6 (Figure 12). 


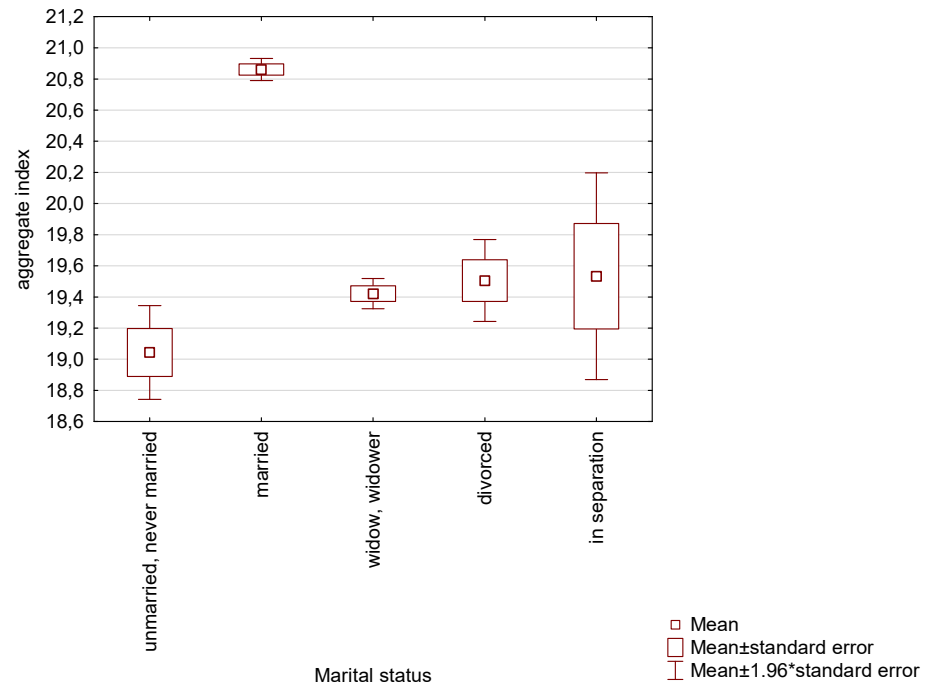

Figure 11. The level of the aggregate indicator in 2018 by marital status of a person representing the household of people aged 60 and older. Source: own elaboration based on data from [136].

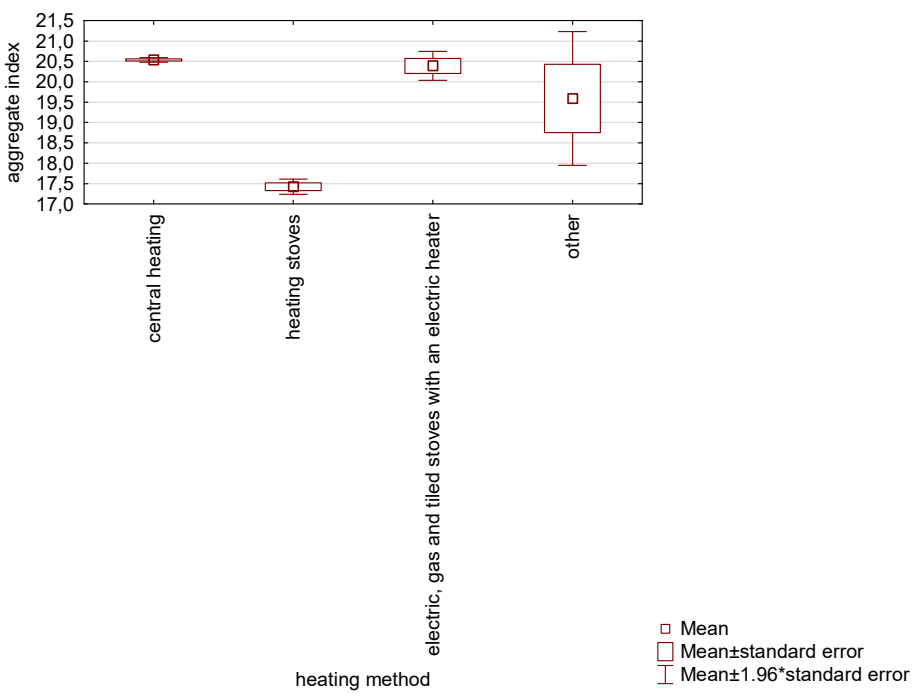

Figure 12. The level of the aggregate indicator in 2018 according to the household heating method of people aged 60 and older. Source: own elaboration based on data from [136].

To summarize, the lowest level of the aggregate indicator concerned the following households: people living on social benefits, with low available income, people with primary or lower secondary education, and houses heated by a solid fuel stove. The level of the aggregate indicator did not exceed 18.1 points.

High aggregate values of the indicator were received in households with the highest levels of income, earning their living from non-manual positions or self-employment, houses run by individuals with higher education, and people living in larger cities (500,000 and more inhabitants). In these types of households, the level of the aggregate indicator was estimated at 21.3 points or more.

\subsection{Types of Households (of People Aged 60 and older), According to Energy Conditions}

As a result of grouping households run by people aged 60 and older, the author distinguished five clusters representing five types of households. The first and largest group, called "moderately energy-satisfied", included households of people with relatively low expenditures on energy carriers and their lowest share in disposable income (6.1\%). A relatively low percentage of households, i.e., $1.8 \%$ of households, indicated the share of 
expenditure on energy carriers, which was established at above $20 \%$ of their disposable income. The basic method of heating a flat/house in this group was central heating. In these farms, over $1 / 5$ of the disposable income was spent on food and non-alcoholic beverages. In the households from the first group (group I), nearly every 10th household did not have appropriate technical and sanitary conditions. Individuals who made up these households had relatively large flats, slightly larger than the average for all respondents. The average usable floor space of a flat in the first cluster was $78.4 \mathrm{~m}^{2}$, and the average number of rooms was estimated at 3.0. People representing households from the first cluster (cluster I) constituted the smallest share of all clusters among those who indicated architectural barriers in their residential buildings. The percentage of households pointing to difficulties with the timely payment of housing fees was close to the average value for all respondents, amounting to $1.6 \%$. Low and very low levels of satisfaction, in terms of the many needs reported by people forming cluster I, remained at an average level, i.e., close to the average level for all surveyed households, lower than in the case of clusters III and V, and higher compared to groups II and IV. As far as satisfying healthcare needs, $6.3 \%$ of the surveyed households indicated a low or very low level of satisfaction of these needs. On the other hand, nearly every fourth household indicated low or very low satisfaction of needs related to culture and recreation, and more than 1/3-those connected with tourism and rest (Table 4).

Table 4. Patterns of consumption of energy carriers of the types of households of people aged 60 and older in Poland in 2018.

\begin{tabular}{|c|c|c|c|c|c|c|}
\hline Characteristics & $\begin{array}{l}\text { 1st Group } \\
\text { Modest, } \\
\text { Energy- } \\
\text { Satisfied }\end{array}$ & $\begin{array}{l}\text { 2nd Group } \\
\text { Energy- } \\
\text { Satisfied }\end{array}$ & $\begin{array}{l}\text { 3rd Group } \\
\text { Energy } \\
\text { Dissatisfied }\end{array}$ & $\begin{array}{l}\text { 4th Group } \\
\text { Energy } \\
\text { Comfort }\end{array}$ & $\begin{array}{l}\text { 5th Group } \\
\text { Energy } \\
\text { Poor }\end{array}$ & $\begin{array}{l}\text { Total } \\
\text { Number }\end{array}$ \\
\hline Number of households & $\mathrm{N}=8434$ & $\mathrm{~N}=5458$ & $\mathrm{~N}=213$ & $\mathrm{~N}=174$ & $\mathrm{~N}=63$ & $\mathrm{~N}=14342$ \\
\hline Aggregate index & 7.6 & 8.6 & 4.1 & 9.7 & 3.2 & 7.9 \\
\hline $\begin{array}{c}\text { The level of expenditure on energy } \\
\text { carriers (PLN) }\end{array}$ & 104 & 340 & 76 & 225 & 450 & 197 \\
\hline $\begin{array}{c}\text { Share of households where expenditure } \\
\text { on energy carriers in available income is } \\
10 \% \text { or more } / 20 \% \text { or more }(\%)\end{array}$ & $19.8 / 1.8$ & $44.4 / 26.1$ & $22.5 / 0.0$ & $12.6 / 29.9$ & $19.1 / 81.0$ & $29.3 / 11.5$ \\
\hline $\begin{array}{l}\text { The share of expenditure on energy } \\
\text { carriers in disposable income (\%) }\end{array}$ & 6.1 & 16.0 & 6.6 & 8.9 & 39.7 & 9.8 \\
\hline $\begin{array}{l}\text { The share of expenditure on energy } \\
\text { carriers in consumer expenditure }(\%)\end{array}$ & 9.5 & 20.4 & 9.9 & 13.5 & 36.3 & 14.2 \\
\hline Available income per person (PLN) & 1676 & 2155 & 1152 & 2390 & 1088 & 1857 \\
\hline $\begin{array}{l}\text { Expenditure on consumer goods and } \\
\text { services in available income }(\%)\end{array}$ & 63.9 & 78.7 & 66.7 & 65.5 & 109.3 & 69.4 \\
\hline $\begin{array}{c}\text { The share of expenditures on food in } \\
\text { available income }(\%)\end{array}$ & 21.1 & 19.4 & 26.9 & 16.8 & 29.7 & 20.5 \\
\hline $\begin{array}{l}\text { The apartment does not have the } \\
\text { appropriate technical and sanitary } \\
\text { conditions-(sewage, water, electricity, } \\
\text { gas, heating installations; good condition } \\
\text { of the roof, walls, floors, windows) }(\%)\end{array}$ & 9.4 & 7.0 & 84.5 & $4.6^{*}$ & 88.9 & 1423 \\
\hline $\begin{array}{l}\text { The apartment does not provide thermal } \\
\text { comfort (the apartment is not cool } \\
\text { enough in the summer and not warm } \\
\text { enough in the winter) (\%) }\end{array}$ & 13.6 & 12.2 & 52.6 & 0.0 & 57.1 & 1965 \\
\hline $\begin{array}{c}\text { There is no hot running water in the } \\
\text { apartment (\%) }\end{array}$ & 0.0 & 0.0 & 100.0 & 0.0 & 100.0 & 276 \\
\hline
\end{tabular}


Table 4. Cont.

\begin{tabular}{|c|c|c|c|c|c|c|}
\hline Characteristics & $\begin{array}{l}\text { 1st Group } \\
\text { Modest, } \\
\text { Energy- } \\
\text { Satisfied }\end{array}$ & $\begin{array}{l}\text { 2nd Group } \\
\text { Energy- } \\
\text { Satisfied }\end{array}$ & $\begin{array}{l}\text { 3rd Group } \\
\text { Energy } \\
\text { Dissatisfied }\end{array}$ & $\begin{array}{l}\text { 4th Group } \\
\text { Energy } \\
\text { Comfort }\end{array}$ & $\begin{array}{l}\text { 5th Group } \\
\text { Energy } \\
\text { Poor }\end{array}$ & $\begin{array}{l}\text { Total } \\
\text { Number }\end{array}$ \\
\hline Usable floor area of the apartment (m2) & 78.4 & 70.4 & 54.6 & 91.1 & 52.7 & 75.0 \\
\hline Number of rooms (mean number) & 3.0 & 2.8 & 1.8 & 3.3 & 1.7 & 2.9 \\
\hline $\begin{array}{l}\text { The apartment is located in a building } \\
\text { with architectural barriers that makes it } \\
\text { difficult to access the apartment (e.g., no } \\
\text { elevator, stairs without driveway, high } \\
\text { thresholds, or no handrails) (\%) }\end{array}$ & 27.9 & 34.6 & 30.5 & 35.1 & 39.7 & 4395 \\
\hline \multicolumn{7}{|l|}{$\begin{array}{l}\text { The method of heating the apartment (\% } \\
\text { from the cluster) }\end{array}$} \\
\hline $\begin{array}{c}\text { Central heating (e.g., from a combined } \\
\text { heat and power plant, local, or } \\
\text { individual boiler room) }\end{array}$ & 85.8 & 89.6 & 6.6 & 88.5 & $9.5 *$ & 12,300 \\
\hline A solid fuel stove & 11.2 & 6.3 & 87.3 & $5.8^{*}$ & 84.1 & 1537 \\
\hline Electric stove & 2.9 & 4.0 & 5.6 & $4.6^{*}$ & $4.8^{*}$ & 483 \\
\hline Other heating & 0.2 & $0.1^{*}$ & $0.5^{*}$ & $1.2 *$ & $1.6^{*}$ & 22 \\
\hline \multicolumn{7}{|l|}{ Satisfying consumer needs } \\
\hline $\begin{array}{l}\text { Bad and rather bad satisfaction of timely } \\
\text { payment of housing fees (fixed fees, rent, } \\
\text { rental costs, etc.) (\% from the cluster) }\end{array}$ & 1.6 & 1.5 & 8.9 & 0.0 & 17.5 & 1.7 \\
\hline $\begin{array}{l}\text { Bad and rather bad satisfaction of culture } \\
\text { and recreation needs ( } \% \text { from the cluster) }\end{array}$ & 24.3 & 22.9 & 40.4 & 14.9 & 61.9 & 24.0 \\
\hline No need for culture and recreation & 16.9 & 14.0 & 39.4 & 11.5 & 28.6 & 16.1 \\
\hline $\begin{array}{l}\text { Bad and rather bad satisfaction of } \\
\text { tourism and leisure needs ( } \% \text { from the } \\
\text { cluster) }\end{array}$ & 34.5 & 30.2 & 49.8 & 21.3 & 58.7 & 33.0 \\
\hline No need for tourism and leisure & 19.4 & 16.8 & 41.3 & 14.9 & 38.1 & 18.7 \\
\hline $\begin{array}{l}\text { Bad and rather bad satisfaction of } \\
\text { healthcare needs ( } \% \text { from the cluster) }\end{array}$ & 9.4 & 10.1 & 19.7 & 4.6 & 39.7 & 9.9 \\
\hline $\begin{array}{l}\text { Bad and rather bad satisfaction of } \\
\text { clothing and footwear needs (\% from the } \\
\text { cluster) }\end{array}$ & 6.3 & 6.7 & 25.8 & 2.9 & 36.5 & 6.8 \\
\hline $\begin{array}{c}\text { Bad and rather bad satisfaction of food } \\
\text { needs (\% from the cluster) }\end{array}$ & 1.5 & 1.6 & 8.0 & 0.6 & 14.3 & 1.7 \\
\hline \multicolumn{7}{|l|}{$\begin{array}{l}\text { The period of construction of the } \\
\text { building ( } \% \text { from the cluster) }\end{array}$} \\
\hline Before 1946 & 18.7 & 16.5 & 56.8 & 15.5 & 61.9 & 2664 \\
\hline In the years 1946-1960 & 13.7 & 11.8 & 26.8 & 10.9 & 27.0 & 1895 \\
\hline In the years 1961-1980 & 42.5 & 43.9 & 11.7 & 35.1 & $9.5^{*}$ & 6074 \\
\hline In the years 1981-1995 & 18.9 & 19.7 & $4.2 *$ & 27.6 & 0.0 & 2724 \\
\hline In the years 1996-2006 & 5.3 & 7.1 & $0.5^{*}$ & 9.2 & 0.0 & 851 \\
\hline \multicolumn{7}{|l|}{ In the years 2007-2011 } \\
\hline after 2011 & 0.9 & 1.0 & $0.0^{*}$ & $1.7 *$ & $1.6^{*}$ & 134 \\
\hline
\end{tabular}

Comment: the percentages for individual clusters are presented horizontally, i.e., the summed results in the rows should give $100 \%$;

* statistically insignificant result. Source: own work. 
The characteristics of the demographic and socioeconomic profiles of the households in cluster I indicated that, more often than in other clusters, these households were created by men $(62 \%)$. These households were relatively the largest, the average number of people, in this case, was estimated at 2.1. The household members of the first group were relatively the youngest, and the average age was 69.6 years; they were married more often than the representatives of other groups examined in the study-the average share amounted to $66 \%$. The level of disposable income in these households reflected an average financial situation, although it was still below the average for all surveyed households. More than $1 / 3$ of the representatives of households in the first cluster were people with primary and vocational education, and less than $1 / 3$ of the respondents declared having secondary education. On the other hand, nearly every fourth person had lower secondary or lower education. People representing the first type were mainly retired (76\%), but also working in blue-collar positions more often than in the case of other clusters (6.5\%). Nearly half of these households were located in the countryside and slightly more than $30 \%$ in towns with less than 100,000 residents (Table 5).

Table 5. Economic and sociodemographic characteristics of the types of households of people aged 60 and older in Poland in 2018 (as a percentage of a given cluster).

\begin{tabular}{|c|c|c|c|c|c|c|}
\hline Characteristics & $\begin{array}{l}\text { 1st Group } \\
\text { Modest, } \\
\text { Energy- } \\
\text { Satisfied }\end{array}$ & $\begin{array}{c}\text { 2nd Group } \\
\text { Energy- } \\
\text { Satisfied }\end{array}$ & $\begin{array}{c}\text { 3rd Group } \\
\text { Energy } \\
\text { Dissatisfied }\end{array}$ & $\begin{array}{l}\text { 4th Group } \\
\text { Energy } \\
\text { Comfort }\end{array}$ & $\begin{array}{c}\text { 5th Group } \\
\text { Energy } \\
\text { Poor }\end{array}$ & $\begin{array}{c}\text { Total } \\
\text { Number }\end{array}$ \\
\hline Number of households & $\mathrm{N}=8434$ & $\mathrm{~N}=5458$ & $\mathrm{~N}=213$ & $\mathrm{~N}=174$ & $\mathrm{~N}=63$ & $\begin{array}{c}\mathrm{N}= \\
14342\end{array}$ \\
\hline Available income per person (PLN) & 1676 & 2155 & 1152 & 2390 & 1088 & 1857 \\
\hline $\begin{array}{l}\text { Expenditure on consumer goods and } \\
\text { services in available income }(\%)\end{array}$ & 63.9 & 78.7 & 66.7 & 65.5 & 109.3 & 69.4 \\
\hline $\begin{array}{c}\text { The share of expenditures on food in } \\
\text { available income }(\%)\end{array}$ & 21.1 & 19.4 & 26.9 & 16.8 & 29.7 & 20.5 \\
\hline \multicolumn{7}{|l|}{ Sex } \\
\hline Male (\%) & 61.9 & 43.2 & 46.0 & 62.6 & 41.3 & 7808 \\
\hline Female $(\%)$ & 38.1 & 56.8 & 54.0 & 37.4 & 58.7 & 6534 \\
\hline Number of people & 2.1 & 1.5 & 1.7 & 1.9 & 1.5 & 1.9 \\
\hline The average age of the person & 69.6 & 70.8 & 72.3 & 69.4 & 72.3 & 70.1 \\
\hline \multicolumn{7}{|l|}{ Marital status } \\
\hline Unmarried, never married (\%) & 4.2 & 5.1 & 17.4 & $2.9 *$ & 20.6 & 690 \\
\hline Married (\%) & 66.3 & 37.9 & 27.7 & 63.8 & $14.3 *$ & 7843 \\
\hline Widow, widower (\%) & 25.1 & 46.7 & 48.4 & 23.0 & 52.4 & 4837 \\
\hline Divorced (\%) & 3.8 & 9.4 & 5.6 & 6.9 & $12.7 *$ & 867 \\
\hline In separation $(\%)$ & 0.6 & 0.9 & $0.9 *$ & $3.5^{*}$ & 0.0 & 105 \\
\hline \multicolumn{7}{|l|}{ Level of education of the personal } \\
\hline $\begin{array}{l}\text { Lower secondary, primary, no formal } \\
\text { education }(\%)\end{array}$ & 24.3 & 15.1 & 67.6 & 9.8 & 65.1 & 3074 \\
\hline Basic vocational (\%) & 34.0 & 24.1 & 23.5 & 21.8 & 22.2 & 4284 \\
\hline $\begin{array}{c}\text { Post-secondary, upper secondary } \\
\text { vocational, upper secondary general (\%) }\end{array}$ & 30.2 & 39.0 & 8.5 & 40.2 & 11.1 & 4767 \\
\hline Tertiary $(\%)$ & 11.6 & 21.8 & $0.5^{*}$ & 28.2 & $1.6^{*}$ & 2217 \\
\hline
\end{tabular}


Table 5. Cont

\begin{tabular}{|c|c|c|c|c|c|c|}
\hline Characteristics & $\begin{array}{l}\text { 1st Group } \\
\text { Modest, } \\
\text { Energy- } \\
\text { Satisfied }\end{array}$ & $\begin{array}{l}\text { 2nd Group } \\
\text { Energy- } \\
\text { Satisfied }\end{array}$ & $\begin{array}{c}\text { 3rd Group } \\
\text { Energy } \\
\text { Dissatisfied }\end{array}$ & $\begin{array}{l}\text { 4th Group } \\
\text { Energy } \\
\text { Comfort }\end{array}$ & $\begin{array}{c}\text { 5th Group } \\
\text { Energy } \\
\text { Poor }\end{array}$ & $\begin{array}{l}\text { Total } \\
\text { Number }\end{array}$ \\
\hline $\begin{array}{l}\text { Households of employees in manual labor } \\
\text { position }(\%)\end{array}$ & 6.5 & 3.0 & $4.7^{*}$ & $4.6^{*}$ & 1.6 & 728 \\
\hline $\begin{array}{c}\text { Households of employees in non-manual } \\
\text { labor position }(\%)\end{array}$ & 4.7 & 5.6 & $0.5 *$ & 10.9 & $3.2 *$ & 718 \\
\hline Households of farmers (\%) & 1.7 & 0.5 & $1.4^{*}$ & 0.0 & $1.6^{*}$ & 179 \\
\hline Households of self-employed (\%) & 2.0 & 1.8 & $0.5^{*}$ & $4.6^{*}$ & 0.0 & 271 \\
\hline Households of retirees (\%) & 76.1 & 78.0 & 67.6 & 73.0 & 60.3 & 10,986 \\
\hline Households of pensioners (\%) & 7.8 & 10.3 & 18.8 & 6.3 & 17.5 & 1283 \\
\hline $\begin{array}{l}\text { Households living on supplementary } \\
\text { welfare allowance }(\%)\end{array}$ & 1.0 & 0.3 & 6.6 & $0.6^{*}$ & $14.3^{*}$ & 127 \\
\hline $\begin{array}{c}\text { Households having income from other } \\
\text { sources (\%) }\end{array}$ & 0.3 & 0.5 & 0.0 & 0.0 & $1.6^{*}$ & 50 \\
\hline \multicolumn{7}{|l|}{ Place of location } \\
\hline Urban area, $\geq 500,000$ inhabitants $(\%)$ & 8.2 & 17.8 & $2.8^{*}$ & 19.0 & $3.2 *$ & 1707 \\
\hline Urban area, 200,000-499,000 inhabitants (\%) & 6.9 & 12.6 & $3.8^{*}$ & 10.9 & $9.5^{*}$ & 1303 \\
\hline Urban area, 100,000-199,000 inhabitants (\%) & 7.4 & 10.9 & 5.2 & 9.2 & $7.9 *$ & 1250 \\
\hline Urban area, 20,000-99,000 inhabitants (\%) & 18.0 & 23.0 & 8.5 & 20.1 & $11.1 *$ & 2831 \\
\hline Urban area, $<20,000$ inhabitants $(\%)$ & 12.4 & 12.0 & 9.9 & 10.3 & $3.2 *$ & 1744 \\
\hline Rural area (\%) & 47.0 & 23.8 & 70.0 & 30.5 & 65.1 & 5507 \\
\hline
\end{tabular}

Comment: the percentages for individual clusters are presented horizontally, i.e., the summed results in the rows should give $100 \%$;

* statistically insignificant result. Source: own work.

In the second group, which is referred to as "energy-demanding", the analysis showed relatively high expenditure on energy carriers and its high share in disposable income $(16 \%)$. Over a quarter of households indicated an over $20 \%$ share of expenses on energy, gas, and other fuels in their available income, and $44 \%$ spent 10 to $20 \%$ of their disposable income on energy carriers. Nearly $90 \%$ of the flats/houses from the second cluster used central heating. The disposable income in these households was higher than in clusters I, III, and V, but lower than in cluster IV. A relatively low percentage of people creating these households reported problems related to the technical and sanitary conditions of the rooms $(7.0 \%)$; however, over $1 / 3$ of the respondents indicated architectural barriers hindering access to housing. The average living space was estimated at over $70 \mathrm{~m}^{2} . \mathrm{In}$ these households, a similar share of respondents, as in the case of cluster I, reported a low or very low level of satisfaction of their consumption needs.

Households in the second cluster were more frequently represented by women (56.8\%) than by men, but the difference was not significant. The average age of the respondents was 70.8 years. These households were most often established by people who lost their spouses (nearly $47 \%$ of widowed individuals). The financial situations of these households were relatively favorable. More than a quarter of individuals representing households from the second cluster declared having higher education, which was regarded as a relatively high level in comparison to other groups. People representing the group in question were mainly retirees $(78 \%)$ or pensioners $(10 \%)$. A relatively small share of these households was located in the countryside (23.8\%), and a relatively large group of survey participants lived in larger cities, with more than 199,000 inhabitants (30.4\%).

In households from the first and second cluster, the technical and sanitary conditions (access to water supply, flushing toilet, bathroom, hot running water, gas, central heating), 
as well as the heating methods were comparable. However, in the second cluster, energy carrier expenditures were at a much higher level, which may suggest different preferences in terms of the comfort of people from both types of households. Perhaps this fact was influenced by the gender of the respondents. The households from the second cluster were more often represented by women, who, according to the literature review, frequently prefer higher temperatures than men.

The next three clusters are groups with considerably fewer cases of households than the previous ones. The third group, referred to as "energy-unsatisfied", are households with the lowest levels of expenditures on energy carriers and the lowest share in disposable income $(6.6 \%)$. The main methods of heating in these households were stoves fired with solid fuels, e.g., coal, wood. In more than half of these households, the respondents reported problems with ensuring the maintenance of adequate heat comfort in living quarters in the winter and summer. In nearly $31 \%$ of households, the survey participants indicated architectural access barriers to housing. The usable areas of flats were relatively small (approximately $55 \mathrm{~m}^{2}$ ). In nearly $9 \%$ of households, the respondents reported problems with the timely payment of residential rents and other housing fees. In a relatively high share of households, the residents also indicated a problem with meeting other consumption needs. For example, in more than $40 \%$ of households, the research indicated a low or very low satisfaction of needs related to culture and recreation, and the needs of tourism and leisure were not satisfied in almost half of the surveyed households. In every fifth household, low and very low satisfaction of healthcare needs was reported; in every fourth household, clothing and footwear needs remained largely unsatisfied (Table 4).

Households included in cluster III-similarly to cluster V-were composed of relatively older people (72.3 years) than in other clusters. About half of these households were managed by widows. The disposable income in the analyzed households was, next to the households from cluster $\mathrm{V}$, the lowest income per person, which indicates a modest financial situation. First, individuals representing this group had the lowest level of education $(67.6 \%)$, or the basic vocational education level $(23.5 \%)$. Here, the groups of individuals with secondary $(8.5 \%)$ and higher education constituted the smallest shares among all the clusters. Retirees $(68 \%)$ and disability pensioners $(20 \%)$ were the two largest socioeconomic groups represented in this cluster. Moreover, the largest percentage of households from cluster III, compared to other clusters, was located in the countryside (70\%) (Table 5).

The presented characteristics of households, in terms of conditions related to heat and electricity in households, indicate the possibility of energy deprivation of household members from the third cluster. Despite the low percentage of households spending more than $20 \%$ of their disposable income on energy carriers, the unfavorable financial situation, poor technical and sanitary conditions, as well as high percentages of households with unmet consumer needs, including thermal comfort, prove a lack of energy comfort. The characteristics of this cluster also show that taking into account only objective features in the field of energy expenditure, such as the share of energy expenditure in disposable income (low in the analyzed cluster), does not provide a full picture, in terms of meeting energy needs. Therefore, it is advisable to create aggregate indicators of energy poverty that take into account both the objective and subjective evaluation of the situation of the respondents.

In the fourth group, which is referred to as "energy comfort", the highest level of the aggregate energy poverty index was recorded, and it amounted to 9.7. These households incurred the expenditure on energy carriers, which is slightly higher than average, with the share that does not exceed $10 \%$ of the household's disposable income. The main method of heating in these households was central heating (89\%). These households were characterized by the most favorable financial situations among all of the examined groups. Moreover, in this group, the share of food expenditure in disposable income was evidence of a better standard of living than in the case of other clusters. These households had the largest usable dwelling areas $\left(91.1 \mathrm{~m}^{2}\right)$. More than $35 \%$ of members representing these households pointed to architectural barriers in their residential building that hinder access 
to housing. This appears to be a relatively serious problem, similar to the circumstances indicated in the case of cluster I. In these households, the lack of satisfaction of consumption needs was reported relatively least frequently among all clusters. Moreover, $15 \%$ of the household representatives complained about the low and very low levels of satisfaction of needs related to culture and recreation, while $21 \%$ complained about unsatisfied needs with regard to tourism and recreation. Less than $5 \%$ of respondents indicated that their healthcare needs were not met to a sufficient degree.

As far as the demographic and socioeconomic profiles of cluster IV-households represented by men accounted for nearly $63 \%$ of the group and it was the highest percentage of all surveyed clusters. These individuals, first, were married-64\%; more often than in other cases, declared having higher education $-28 \%$ or secondary education $-40 \%$. People with the lowest levels of education represented the smallest share, i.e., $10 \%$ among all of the analyzed clusters These households were located mainly in larger cities with more than 199,000 inhabitants (30\%) and in villages (31\%).

Cluster V, which constituted the smallest group, including 63 households, was called "energy-poor". These households indicated a high level of expenditure on energy carriers and a very high percentage of such costs in their disposable income (40\%). Residential buildings were heated mainly with solid fuels, such as coal or wood. In these households, it was observed that the level of consumer spending exceeded the level of their disposable income, which may be related to the indebtedness of the analyzed households. This fact may also reflect the tendency for income to be underestimated by some representatives of households; therefore, analyzing the expenses of households may prove to be more effective as an indication of their actual circumstances.

The level of disposable income in these households was the lowest among all clusters, and the percentage of food expenditure was the highest among all the examined clusters. It is worth mentioning that over $14 \%$ of these households indicated the unmet needs related to food consumption. Among other problems that appeared in the households from the fifth cluster, the respondents indicated architectural barriers in residential buildings that made access to housing difficult. In this case, the issue was pointed out by the largest share of households from all groups, i.e., nearly $40 \%$. These households occupied the smallest usable floor space of a flat, i.e., $52.7 \mathrm{~m}^{2}$.

Households in the fifth cluster were represented by women more often than in other clusters (59\%), and more than half of the households included individuals who lost their spouses (widows and widowers). These people declared having a low level of education, i.e., lower secondary and lower level of education (65\%) and vocational education was pointed out by $22 \%$ of the share. People who make up these households lived mainly in the countryside $(65 \%)$. It was also noticed that in cluster $\mathrm{V}$, similar to cluster III, people representing households were the oldest, i.e., they were over 72 years old, compared to 69-70-year-old individuals in other clusters.

Households from clusters III and V lived in older residential buildings. In these clusters, high percentages of respondents indicated a poor technical and sanitary condition of the dwellings they occupied. In cluster $\mathrm{V}$, a large percentage of respondents pointed to architectural barriers hindering access to the residential building.

\section{Discussion}

Housing conditions, including those related to energy carriers, in Polish households run by older people appear to be improving. However, the studies conducted by other authors do not clearly indicate a consistent improvement in the field of energy poverty: in some countries, the percentage of households affected by this problem seems to be decreasing [155], while in other countries, energy poverty is spreading [156].

In households managed by elderly people, the living conditions in terms of ensuring an adequate energy standard are still worse than in households of younger people. Research shows [157] that seniors-due to physiological changes occurring with age-are more exposed to very low and very high temperatures. It's worth adding, physiological changes 
in the organisms of the elderly, and the more difficult financial situations of this group, often lead to insufficient provision of adequate thermal conditions in the apartment, which is confirmed by own research and other studies [158]. Research emphasizes that the elderly population is more exposed to extreme temperatures in both winter and summer $[159,160]$.

Research from Australia has shown that elderly people with low incomes much less frequently used devices, such as air conditioners, to improve their quality of life than younger people [161]. The study by A.C. Sadath and R.H. Acharya [162] finds that income poverty and energy poverty are commensurate with each other. The research [163] also draws attention to the ineffectiveness of heating systems in many apartments occupied by the elderly. The study emphasizes the need to improve energy policy in order to align the requirements for the thermal performance of buildings with the wider healthcare plan and the specific needs of older people.

The conducted research showed that people living in the countryside, in multi-person households, with a low level of education, and heating their homes with obsolete heating equipment, have a greater chance of remaining at risk of energy poverty than people living in other types of households. These results are consistent with analyses from other countries where the authors emphasize that, in rural areas, individuals face a greater risk of energy poverty than those living in urban areas $[155,164]$.

Other studies [1] confirm the positive impact of higher education on energy satisfaction. However, research [165] shows that the education level of households does not have any significant effect on energy poverty, although, on the other hand, in households with persons having higher education, their awareness of energy conservation measures is linked to a reduction in energy poverty, particularly in households having lower income.

People experiencing energy poverty often have to choose between warmth and food $[166,167]$. Satisfying other consumption needs also means deprivation in the analyzed households. In some of the surveyed households, it was found that the needs in terms of culture and recreation, tourism and leisure, healthcare, clothing, and footwear were poorly (or very poorly) met. The research findings also show that, in other households these needs do not exist at all. Thus, the results of other studies [162,163] have confirmed that energy poverty also has an impact on the health of residents.

Many studies show a link among gender, energy, and poverty. It turns out that women are more exposed to energy poverty [159,168-172].

In the third and fifth cluster, high percentages of households equipped with a solid fuel stove, additionally indicating an unfavorable financial situation, indicate the phenomenon of energy deprivation, which may lead to adverse health effects [173]. Heating your home with a coal and wood stove poses a greater risk of lung disease, especially among energypoor people. Inefficient heat sources increase indoor air pollution. Nearly $40 \%$ of people who have a coal or wood stoves suffer from respiratory diseases (including asthma and bronchitis). Moreover, energy-poor people who heat their apartments with a solid fuel stove in a flat area have a $27 \%$ higher risk of getting a respiratory disease than energy-poor people whose apartments are connected to the heating network [174]. It should also be noted that heating with a solid fuel stove (coal, wood) is more burdensome. Manual heating and maintaining a stable temperature require storage and systematic refilling of fuel. Individual heating also requires effort: getting up at night, carrying fuel, cleaning the stove, as well as the use of additional equipment-heat guns, moisture absorbers, or air purifiers. It is also associated with additional energy consumption and higher costs, which is particularly burdensome for pensioners' household budgets. It probably also has a significant impact on lowering the standard of living of these people [174]. In Poland, the use of hard coal stoves in rural areas is very high [175].

Households from clusters with the least favorable financial situations lived in older residential buildings. In these clusters, relatively high of respondents indicated a poor technical and sanitary condition of the dwellings they occupied. The respondents also pointed to architectural barriers hindering access to the residential building. As a rule, new homes are usually safer and healthier because they are built in accordance with modern 
building standards, technologies, and regulations-as well as with (constantly changing) consumer expectations [176,177]. However, they are usually inhabited by younger people. With this in mind, appropriate support programs should be targeted at residents of older homes, especially those who are elderly and whose disposable incomes do not allow for investments in the modernization of housing premises. It is also worth conducting initiatives to support these households (i.e., with installations using renewable energy sources) [178].

\section{Conclusions}

Households consisting of elderly people are strongly diversified (i.e., in terms of housing conditions, including energy conditions). Research carried out in Poland shows that a minor percentage of households of people aged 60 and older are in a very difficult situation, in terms of having their needs satisfied, in relation to energy carriers. These are mainly people with low levels of education, living on social benefits, with low levels of disposable income, living in the countryside.

Therefore, the energy deprivation of Polish households, of people aged 60 and older, seems to occur mainly among specific socio-professional clusters, consisting of households with persons with lower education, people with low income, as well as those living in the countryside. The conducted research—similar to the previous work [1]—exposed that the possibility of perceive energy poverty solely through the prism of income-based indicators may result in the failure to detect all energy-impoverished persons. The age and gender of the person representing the household are important demographic determinants of energy poverty. It was noticed that households represented by men aged 60 and older have a better energy supply than households run by women. Households with people aged 60 and over, in which a woman is the head of the household, are more likely to suffer from energy poverty. Similarly, the older the person representing the household, the greater the likelihood of reporting that the energy comfort needs are not met. It seems that these features are related, inter alia, to the physiology of these people. Women need higher ambient temperatures. With age, people move less, which also affects the problem of thermal discomfort experienced in the immediate environment.

Polish households of people aged 60 and older were classified into five groups according to the spending on energy, gas, and other fuels and meeting their needs related to thermal conditions (moderately energy-satisfied, energy-demanding, energy-unsatisfied, energy-comfort, and energy-poor). The identified groups are heterogeneous in terms of the variables under consideration.

The research indicated the existence of varied patterns of consumption of energy carriers in households of people aged 60 and older in Poland and dissimilarities in terms of the reasons for energy poverty among households, of people aged 60 and older. The most important factors influencing energy poverty in the households of people aged 60 and older involved income situations and social and professional characteristics.

Research findings provide critical implications for policymakers whose goal is to alleviate energy poverty. Households of people aged 60 and over often have low income, which prevents them from covering their energy expenditures and ensuring adequate housing conditions. Until their incomes rise, they will not be able to spend more on access to energy services, and their deprivation will continue. Thus, it is necessary to raise income levels or introduce appropriate legal solutions (support programs) that will enable people from these households to have access to an adequate amount of energy. This applies especially to people living in the countryside, who support themselves using social benefits. Income from social benefits for older people is usually low and is not sufficient to cover basic needs. Obsolete heating solutions do not ensure proper energy comfort in these households. Expenditures on electricity and fuel accounts for a significant share of household income, leaving limited funds to be spent on other necessities and services. Reliance on traditional fuels, such as hard coal, is a major problem in rural areas. It is, 
therefore, necessary to extend the gas pipeline network, so that residents in rural areas can use natural gas as well.

Funding: This research and the APC were funded by the Warsaw University of Technology.

Institutional Review Board Statement: Not applicable.

Informed Consent Statement: Not applicable.

Data Availability Statement: The data presented in this study are available upon request from the corresponding author due to restrictions.

Acknowledgments: The author would like to thank the anonymous reviewers for their valuable comments and suggestions to improve the quality of the paper.

Conflicts of Interest: The author declares no conflict of interest.

\section{References}

1. Piekut, M. Patterns of Energy Consumption in Polish One-Person Households. Energies 2020, 13, 5699. [CrossRef]

2. Kastner, I.; Matthies, E. Investments in renewable energies by German households: A matter of economics, social influences and ecological concern? Energy Res. Soc. Sci. 2016, 17, 1-9. [CrossRef]

3. Bouzarovski, S.; Petrova, S. A global perspective on domestic energy deprivation: Overcoming the energy poverty-fuel poverty binary. Energy Res. Soc. Sci. 2015, 10, 31-40. [CrossRef]

4. Rudge, J.; Gilchrist, R. Excess winter morbidity among older people at risk of cold homes: A population-based study in a London borough. J. Public Health 2005, 27, 353-358. [CrossRef] [PubMed]

5. Karpinska, L.; Śmiech, S. Invisible energy poverty? Analysing housing costs in Central and Eastern Europe. Energy Res. Soc. Sci. 2020, 70, 101670. [CrossRef]

6. Cong, S.; Nock, D.; Qiu, Y.L.; Xing, B. The Energy Equity Gap: Unveiling Hidden Energy Poverty. Nat. Portf. J. 2021. in review. [CrossRef]

7. Simcock, N.; Thomson, H.; Petrova, S.; Bouzarovski, S. Energy Poverty and Vulnerability: A Global Perspective; Routledge: New York, NY, USA, 2017.

8. Team, A.; Baffert, C. Energy poverty and vulnerable consumers in the energy sector across the EU: Analysis of policies and measures. Policy 2015, 2, 64-89.

9. Kerr, N.; Gillard, R.; Middlemiss, L. Politics, problematisation, and policy: A comparative analysis of energy poverty in England, Ireland and France. Energy Build. 2019, 194, 191-200. [CrossRef]

10. Okushima, S. Gauging energy poverty: A multidimensional approach. Energy 2017, 137, 1159-1166. [CrossRef]

11. Karpinska, L.; Śmiech, S. Breaking the cycle of energy poverty. Will Poland make it? Energy Econ. 2021, 94, 105063. [CrossRef]

12. Janikowska, O.; Kulczycka, J. Just Transition as a Tool for Preventing Energy Poverty among Women in Mining Areas-A Case Study of the Silesia Region, Poland. Energies 2021, 14, 3372. [CrossRef]

13. Moore, R. Definitions of fuel poverty: Implications for policy. Energy Policy 2012, 49, 19-26. [CrossRef]

14. Bouzarovski, S.; Petrova, S.; Sarlamanov, R. Energy poverty policies in the EU: A critical perspective. Energy Policy 2012, 49, 76-82. [CrossRef]

15. Karásek, J.; Pojar, J. Programme to reduce energy poverty in the Czech Republic. Energy Policy 2018, 115, 131-137. [CrossRef]

16. Vespa, J.; Armstrong, D.M.; Medina, L. Demographic Turning Points for the United States: Population Projections for 2020 to 2060; US Department of Commerce, Economics and Statistics Administration, US Census Bureau: Washington, DC, USA, 2018.

17. England, K.; Azzopardi-Muscat, N. Demographic trends and public health in Europe. Eur. J. Public Health 2017, 27, 9-13. [CrossRef] [PubMed]

18. Neacsa, A.; Panait, M.; Muresan, J.D.; Voica, M.C. Energy poverty in European Union: Assessment difficulties, effects on the quality of life, mitigation measures. some evidences from Romania. Sustainability 2020, 12, 4036. [CrossRef]

19. Njiru, C.W.; Letema, S.C. Energy poverty and its implication on standard of living in Kirinyaga, Kenya. J. Energy 2018, 2018, 3196567. [CrossRef]

20. Oliveras, L.; Artazcoz, L.; Borrell, C.; Palència, L.; López, M.J.; Gotsens, M.; Peralta, A.; Marí-Dell'Olmo, M. The association of energy poverty with health, health care utilisation and medication use in southern Europe. SSM-Popul. Health 2020, 12, 100665. [CrossRef]

21. Robić, S.; Ančić, B. Exploring Health Impacts of Living in Energy Poverty: Case Study Sisak-Moslavina County, Croatia. Energy Build. 2018, 169, 379-387. [CrossRef]

22. Rybárová, D. Assessing progress towards responsible consumption and production. SHS Web Conf. 2020, 83, 01059. [CrossRef]

23. Şahin, D.S.; Özer, Ö.; Yanardă̆, M.Z. Perceived social support, quality of life and satisfaction with life in elderly people. Educ. Gerontol. 2019, 45, 69-77. [CrossRef]

24. Xie, L. Age-friendly communities and life satisfaction among the elderly in urban China. Res. Aging 2018, 40, 883-905. [CrossRef] 
25. Tran, T.Q.; Van Vu, H. A microeconometric analysis of housing and life satisfaction among the Vietnamese elderly. Qual. Quant. 2018, 52, 849-867. [CrossRef]

26. Büyüközkan, G.; Karabulut, Y.; Mukul, E. A novel renewable energy selection model for United Nations' sustainable development goals. Energy 2018, 165, 290-302. [CrossRef]

27. McCollum, D.L.; Echeverri, L.G.; Busch, S.; Pachauri, S.; Parkinson, S.; Rogelj, J.; Riahi, K. Connecting the sustainable development goals by their energy inter-linkages. Environ. Res. Lett. 2018, 13, 033006. [CrossRef]

28. Qugaard, M. Political Globalization: State, Power, and Social Forces; Palgrave Macmillan: New York, NY, USA, 2004.

29. Schmukler, S.L.; Abraham, F. Financial Globalization: A Glass Half Empty? World Bank: Washington, DC, USA, 2017.

30. Sánchez-López, C.; Aceytuno, M.T.; De Paz-Bañez, M.A. Inequality and globalisation: Analysis of European countries. Econ. Sociol. 2019, 12, 84-100. [CrossRef] [PubMed]

31. Castaño-Rosa, R.; Solís-Guzmán, J.; Rubio-Bellido, C.; Marrero, M. Towards a multiple-indicator approach to energy poverty in the European Union: A review. Energy Build. 2019, 193, 36-48. [CrossRef]

32. Boemi, S.N.; Papadopoulos, A.M. Energy poverty and energy efficiency improvements: A longitudinal approach of the Hellenic households. Energy Build. 2019, 197, 242-250. [CrossRef]

33. Balcerzak, A.P. Quality of institutions in the European Union countries. Application of TOPSIS based on entropy measure for objective weighting. Acta Polytech. Hung. 2020, 17, 101-122. [CrossRef]

34. Halaskova, M.; Gavurova, B.; Korony, S. Change of EU28 countries research and development indicators between 2010 and 2015. Econ. Sociol. 2020, 13, 230-248. [CrossRef]

35. Lee, Y.; Kim, B.; Hwang, H. Which Institutional Conditions Lead to a Successful Local Energy Transition? Applying Fuzzy-Set Qualitative Comparative Analysis to Solar PV Cases in South Korea. Energies 2020, 13, 3696. [CrossRef]

36. Lin, M.-X.; Liou, H.M.; Chou, K.T. National Energy Transition Framework toward SDG7 with Legal Reforms and Policy Bundles: The Case of Taiwan and Its Comparison with Japan. Energies 2020, 13, 1387. [CrossRef]

37. Edison, H.J.; Levine, R.; Ricci, L.; Sløk, T. International financial integration and economic growth. J. Int. Money Financ. 2002, 21, 749-776. [CrossRef]

38. Skare, M.; Porada-Rochoń, M. Financial and economic development link in transitional economies: A spectral Granger causality analysis 1991-2017. Oecon. Copernic. 2019, 10, 7-35. [CrossRef]

39. Stavytskyy, A.; Kharlamova, G.; Giedraitis, V.; Sengul, E.C. Gravity model analysis of globalization process in transition economies. J. Int. Stud. 2019, 12, 322-341. [CrossRef]

40. Ginevičius, R. Multi-criteria assessment of socioeconomic systems' conditions based on hierarchically structured indicator systems. Econ. Sociol. 2020, 13, 256-266. [CrossRef]

41. Fraune, C.; Knodt, M. Sustainable energy transformations in an age of populism, post-truth politics, and local resistance. Energy Res. Soc. Sci. 2018, 43, 1-7. [CrossRef]

42. Lacey-Barnacle, M.; Robison, R.; Foulds, C. Energy justice in the developing world: A review of theoretical frameworks, key research themes and policy implications. Energy Sustain. Dev. 2020, 55, 122-138. [CrossRef]

43. Newell, P. Trasformismo or transformation? The global political economy of energy transitions. Rev. Int. Political Econ. 2019, 26, 25-48. [CrossRef]

44. Škare, M.; Franc-Dąbrowska, J.; Cvek, D. Cointegration analysis and VECM of FDI, employment, export and GDP in Croatia (2002-2017) with particular reference to the global crisis and poor macroeconomic governance. Equilib. Q. J. Econ. Econ. Policy 2020, 15, 761-783. [CrossRef]

45. Gavurova, B.; Soltes, M.; Kovac, V. Application of cluster analysis in process of competitiveness modelling of Slovak Republic regions. Transform. Bus. Econ. 2017, 16, 129-147.

46. Szopik-Depczyńska, K.; Kędzierska-Szczepaniak, A.; Szczepaniak, K.; Cheba, K.; Gajda, W.; Ioppolo, G. Innovation in sustainable development: An investigation of the EU context using 2030 agenda indicators. Land Use Policy 2018, 79, 251-262. [CrossRef]

47. Kisel'áková, D.; Šofranková, B.; Onuferová, E.; Čabinová, V. The evaluation of competitive position of EU-28 economies with using global multi-criteria indices. Equilib. Q. J. Econ. Econ. Policy 2019, 14, 441-462. [CrossRef]

48. Androniceanu, A.M.; Kinnunen, J.; Georgescu, I.; Androniceanu, A. A Multidimensional Approach to Competitiveness, Innovation and Well-Being in the EU Using Canonical Correlation Analysis. J. Compet. 2020, 12, 5-21. [CrossRef]

49. Kijek, A.; Matras-Bolibok, A. Technological convergence across European regions. Equilibrium. Q. J. Econ. Econ. Policy 2020, 15, 295-313. [CrossRef]

50. Cutrini, E. Economic integration, structural change, and uneven development in the European Union. Struct. Chang. Econ. Dyn. 2019, 50, 102-113. [CrossRef]

51. Szopik-Depczyńska, K.; Cheba, K.; Bąk, I.; Stajniak, M.; Simboli, A.; Ioppolo, G. The study of relationship in a hierarchical structure of EU sustainable development indicators. Ecol. Indic. 2018, 90, 120-131. [CrossRef]

52. Kuc-Czarnecka, M.; Lo Piano, S.; Saltelli, A. Quantitative Storytelling in the Making of Composite Indicator. Soc. Indic. Res. 2020. [CrossRef]

53. Pietrzak, M.B.; Balcerzak, A.P.; Gajdos, A.; Arendt, Ł. Entrepreneurial environment at regional level: The case of Polish path towards sustainable socio-economic development. Entrep. Sustain. Issues 2017, 5, 190-203. [CrossRef]

54. Rollnik-Sadowska, E.; Dabrowska, E. Cluster analysis of effectiveness of labour market policy in the European Union. Oecon. Copernic. 2018, 9, 143-158. [CrossRef] 
55. Chocholatá, M.; Furková, A. The analysis of employment rates in the context of spatial connectivity of the EU regions. Equilib. Q. J. Econ. Econ. Policy 2018, 13, 181-213. [CrossRef]

56. Markhaichuk, M.; Zhuckovskaya, I. The spread of the regional intellectual capital: The case of the Russian Federation. Oecon. Copernic. 2019, 10, 89-111. [CrossRef]

57. Thalassinos, E.; Cristea, M.; Noja, G.G. Measuring active ageing within the European Union: Implications on economic development. Equilib. Q. J. Econ. Econ. Policy 2019, 14, 591-609. [CrossRef]

58. Bilan, Y.; Mishchuk, H.; Roshchyk, I.; Kmecova, I. An Analysis of Intellecutal Potential and its Impact on the Social and Economic Development of European Countries. J. Compet. 2020, 12, 22-38. [CrossRef]

59. Gajdos, A.; Arendt, L.; Balcerzak, A.P.; Pietrzak, M.B. Future Trends of Labour Market Polarisation in Poland. The Perspective of 2025. Transform. Bus. Econ. 2020, 19, 114-135.

60. Kónya, I.; Ohashi, H. International Consumption Patterns among High-income Countries: Evidence from the OECD Data. Rev. Int. Econ. 2007, 15, 744-757. [CrossRef]

61. Horáková, M. Consumer behavior of college students in the Czech Republic. J. Compet. 2015, 7, 68-85.

62. Grybaitè, V.; Stankevičienè, J. An empirical analysis of factors affecting sharing economy growth. Oecon. Copernic. 2018, 9 , 635-654. [CrossRef]

63. Jankiewicz, M.; Pietrzak, M.B. Assessment of trends in the share of expenditure on services and food in the visegrad group member states. Int. J. Bus. Soc. 2020, 21, 977-996. [CrossRef]

64. Tukker, A.; Charter, M.; Vezzoli, C.; Stø, E.; Andersen, M.M. Emerging sustainable consumption patterns in Central Eastern Europe, with a specific focus on Hungary. In System Innovation for Sustainability 1; Routledge: New York, NY, USA, 2017; pp. 311-328.

65. Jiglau, G.; Sinea, A.; Dubois, U.; Biermann, P. Perspectives on Energy Poverty in Post-Communist Europe; Routledge: New York, NY, USA, 2020.

66. General, A. Transforming our World: The 2030 Agenda for Sustainable Development; General Assembly; United Nations: New York, NY, USA, 2015.

67. Eurostat. Energy Balance Sheets. Available online: https:/ / ec.europa.eu/eurostat/web/energy/data/database (accessed on 29 April 2021).

68. Okushima, S. Understanding regional energy poverty in Japan: A direct measurement approach. Energy Build. 2019, 193, 174-184. [CrossRef]

69. González-Eguino, M. Energy poverty: An overview. Renew. Sustain. Energy Rev. 2015, 47, 377-385. [CrossRef]

70. Bardazzi, R.; Pazienza, M.G. Switch off the light, please! Energy use, aging population and consumption habits. Energy Econ. 2017, 65, 161-171. [CrossRef]

71. CSO Information of the Minister of Health on the impact of demographic changes and aging of the society on the organization of the health care system and the National Health Program. In Proceedings of the Parliamentary Senior Policy Committee, Warsaw, Poland, 19 February 2016; Available online: https:/ / stat.gov.pl/files/gfx/portalinformacyjny/pl/defaultaktualnosci/5468/24/ 1/1/ludnosc_w_wieku_60._struktura_demograficzna_i_zdrowie.pdf (accessed on 25 August 2021). (In Polish).

72. Statistics Poland. Household Budget 2006; Statistics Poland: Warsaw, Poland, 2007.

73. Statistics Poland. Household Budget 2016; Statistics Poland: Warsaw, Poland, 2017.

74. Statistics Poland. Household Budget 2018; Statistics Poland: Warsaw, Poland, 2019.

75. Zhang, F.; Zhang, C.; Hudson, J. Housing conditions and life satisfaction in urban China. Cities 2018, 81, 35-44. [CrossRef]

76. Fernández-Portero, C.; Alarcón, D.; Padura, Á.B. Dwelling conditions and life satisfaction of older people through residential satisfaction. J. Environ. Psychol. 2017, 49, 1-7. [CrossRef]

77. Vanleerberghe, P.; De Witte, N.; Claes, C.; Schalock, R.L.; Verté, D. The quality of life of older people aging in place: A literature review. Qual. Life Res. 2017, 26, 2899-2907. [CrossRef] [PubMed]

78. Siedlecka, A.; Smarzewska, A. Housing conditions as a measure of the objective quality of life of people with disabilities, Scientific Papers of the Warsaw University of Life Sciences. Economics and Organization of Food Economy (Warunki mieszkaniowe jako miernik obiektywnej jakości życia osób niepełnosprawnych). Zesz. Nauk. Szk. Głównej Gospod. Wiejskiego. Ekon. I Organ. Gospod. Żywnościowej. 2013, 102, 155-166. (In Polish)

79. Andrzejewski, A. Housing Policy; Państwowe Wydawnictwo Ekonomiczne: Warsaw, Poland, 1987; pp. 1-319. (In Polish)

80. Kochera, A.; Straight, A.; Guterbock, T. Beyond 50.05: A report to the nation on livable communities-Creating environments for successful aging. Natl. Acad. Sci. Eng. Med. 2005.

81. Mulliner, E.; Riley, M.; Maliene, V. Older People's Preferences for Housing and Environment Characteristics. Sustainability 2020, 12, 5723. [CrossRef]

82. Tonn, B.; Hawkins, B.; Rose, E.; Marincic, M. Income, housing and health: Poverty in the United States through the prism of residential energy efficiency programs. Energy Res. Soc. Sci. 2021, 73, 101945. [CrossRef]

83. ASHRAE Standard 55: Thermal Environmental Conditions for Human Occupancy; American Society of Heating Refrigerating and Air-Conditioning Engineers: Atlanta, GA, USA, 2004.

84. Zrałek, M. Satisfying the Housing Needs of the Elderly. Dilemmas and Directions of Changes (Zaspokojenie potrzeb mieszkaniowych osób starszych. Dylematy i kierunki zmian.). In The Situation of Elderly People; Rządowa Rada Ludnościowa: Warsaw, Poland, 2012; p. 103. (In Polish) 
85. Bartoszek, A.; Niezabitowska, E.; Kucharczyk-Brus, B.; Niezabitowski, M. Living conditions for seniors. Main research findings. In Medical, Psychological, Sociological and Economic Aspects of Aging in Poland; Mossakowska, M., Więcek, A., Błędowski, P., Eds.; Termedia Medical Publishing House: Poznań, Poland, 2012. (In Polish)

86. Strączkowski, Ł.; Boruta, M. Seniors' housing conditions and decisions on the local real estate market. Crac. Rev. Econ. Manag. 2018, 3, 69-81. (In Polish)

87. Kramer, C.; Pfaffenbach, C. Should I stay or should I go? Housing preferences upon retirement in Germany. J. Hous. Built Environ. 2016, 31, 239-256. [CrossRef]

88. Hui, E.C.M.; Wong, F.K.W.; Chung, K.W.; Lau, K.Y. Housing affordability, preferences and expectations of elderly with government intervention. Habitat Int. 2014, 43, 11-21. [CrossRef]

89. Abramsson, M.; Andersson, E. Changing Preferences with Ageing-Housing Choices and Housing Plans of Older People. Hous. Theory Soc. 2016, 33, 217-241. [CrossRef]

90. Costa-Font, J.; Elvira, D.; Mascarilla-Miró, O. 'Ageing in Place'? Exploring Elderly People's Housing Preferences in Spain. Urban. Stud. 2009, 46, 295-316. [CrossRef]

91. Jong, P.; Rouwendal, J.; Hattum, P.; Brouwer, A. Housing Preferences of an Ageing Population: Investigation in the Diversity Among Dutch Older Adults. SSRN Electron. J. 2012. Available online: https://www.netspar.nl/assets/uploads/024_De_Jong.pdf (accessed on 28 August 2021). [CrossRef]

92. Ziółkowska, K.; Lis, M.; Miazga, A.; Sałach, K.; Szpor, A. Energy Poverty in Poland-Diagnosis and Recommendations; Institute for Structural Research: Warsaw, Poland, 2016; Available online: https:/ /ibs.org.pl/publications/ubostwo-energetyczne-w-polscediagnoza-i-rekomendacje/ (accessed on 28 August 2021). (In Polish)

93. Abbas, K.; Li, S.; Xu, D.; Baz, K.; Rakhmetova, A. Do socioeconomic factors determine household multidimensional energy poverty? Empirical evidence from South Asia. Energy Policy 2020, 146, 111754. [CrossRef]

94. Diaz-Serrano, L. Disentangling the housing satisfaction puzzle: Does homeownership really matter? J. Econ. Psychol. 2009, 30, 745-755. [CrossRef]

95. Hu, F. Homeownership and subjective wellbeing in urban China: Does owning a house make you happier? Soc. Indic. Res. 2013, 110, 951-971. [CrossRef]

96. Lu, M. Determinants of residential satisfaction: Ordered logit vs. regression models. Growth Chang. 1999, 30, 264-287. [CrossRef]

97. Varady, D.P.; Walker, C.C.; Wang, X. Voucher recipient achievement of improved housing conditions in the US: Do moving distance and relocation services matter? Urban. Stud. 2001, 38, 1273-1304. [CrossRef]

98. Vera-Toscano, E.; Ateca-Amestoy, V. The relevance of social interactions on housing satisfaction. Soc. Indic. Res. 2008, 86, 257-274. [CrossRef]

99. Lee, E.; Park, N.-K. Housing satisfaction and quality of life among temporary residents in the United States. Hous. Soc. 2010, 37, 43-67. [CrossRef]

100. Amole, D. Residential satisfaction in students' housing. J. Environ. Psychol. 2009, 29, 76-85. [CrossRef]

101. Li, Z.; Wu, F. Residential satisfaction in China's informal settlements: A case study of Beijing, Shanghai, and Guangzhou. Urban. Geogr. 2013, 34, 923-949. [CrossRef]

102. Zhu, L.Y.; Shelton, G.G. The relationship of housing costs and quality to housing satisfaction of older American homeowners: Regional and racial differences. Hous. Soc. 1996, 23, 15-35. [CrossRef]

103. Nguyen, A.T.; Tran, T.Q.; Vu, H.V.; Luu, D.Q. Housing satisfaction and its correlates: A quantitative study among residents living in their own affordable apartments in urban Hanoi, Vietnam. Int. J. Urban. Sustain. Dev. 2018, 10, 79-91. [CrossRef]

104. Van Hoof, J.; Schellen, L.; Soebarto, V.; Wong, J.K.; Kazak, J.K. Ten questions concerning thermal comfort and ageing. Build. Environ. 2017, 120, 123-133. [CrossRef]

105. Collins, K.J.; Exton-Smith, A.N.; Dore, C. Urban hypothermia: Preferred temperature and thermal perception in old age. Br. Med. J. Clin. Res. Ed. 1981, 282, 175-177. [CrossRef]

106. Natsume, K.; Ogawa, T.; Sugenoya, J.; Ohnishi, N.; Imai, K. Preferred ambient temperature for old and young men in summer and winter. Int. J. Biometeorol. 1992, 36, 1-4. [CrossRef]

107. Hashiguchi, N.; Tochihara, Y.; Ohnaka, T.; Tsuchida, C.; Otsuki, T. Physiological and subjective responses in the elderly when using floor heating and air conditioning systems. J. Physiol. Anthropol. Appl. Hum. Sci. 2004, 23, 205-213. [CrossRef]

108. Schellen, L.; van Marken Lichtenbelt, W.D.; Loomans, M.G.L.C.; Toftum, J.; de Wit, M.H. Differences between young adults and elderly in thermal comfort, productivity, and thermal physiology in response to a moderate temperature drift and a steady-state condition. Indoor Air 2010, 20, 273-283. [CrossRef] [PubMed]

109. DeGroot, D.W.; Kenney, W.L. Impaired defense of core temperature in aged humans during mild cold stress. Am. J. Physiol. Regul. Integr. Comp. Physiol. 2007, 292, R103-R108. [CrossRef]

110. Fanger, P.O. Thermal Comfort: Analysis and Applications in Environmental Engineering; Danish Technical Press: Copenhagen, Denmark, 1970.

111. Rohles, F.H.; Johnson, M.A. Thermal comfort in the elderly. ASHRAE Trans. 1972, 8, 131-137.

112. Van Hoof, J.; Hensen, J.L.M. Thermal comfort and older adults. Gerontechnology 2006, 4, 223-228.

113. Fanger, P.O.; Langkilde, G. Interindividual differences in ambient temperatures preferred by seated persons. ASHRAE Trans. 1975, 81, 140-147. 
114. ASHRAE. Handbook Fundamentals; American Society of Heating Refrigerating and Air-Conditioning Engineers: Atlanta, GA, USA, 2009.

115. Van Praag, B.M.; Ferrer-i-Carbonell, A. Happiness Quantified: A Satisfaction Calculus Approach; Oxford University Press: Oxford, UK, 2004.

116. Hasan, N.L.; Mohamad, O.; Ramayah, T. The determinants of housing satisfaction level: A study on residential development project by Penang Development Corporation (PDC). J. Kemanus. 2005, 6, 1-20.

117. Stephens, C.; Allen, J. Older people as active agents in their neighborhood environments: Moving house can improve quality of life. The Gerontologist, 19 May 2021.

118. Varady, D.P.; Preiser, W.F. Scattered-site public housing and housing satisfaction: Implications for the new public housing program. J. Am. Plan. Assoc. 1998, 64, 189-207. [CrossRef]

119. Nakano, J.; Tanabe, S.; Kimura, K. Differences in perception of indoor environment between Japanese and non-Japanese workers. Energy Build. 2002, 34, 615-621. [CrossRef]

120. Parsons, K.C. Human Thermal Environments: The Effects of Hot, Moderate, and Cold Environments on Human Health, Comfort, and Performance; Taylor \& Francis: Abingdon, UK, 2014.

121. Karjalainen, S. Gender differences in thermal comfort and use of thermostats in everyday thermal environments. Build. Environ. 2007, 42, 1594-1603. [CrossRef]

122. Karjalainen, S. Thermal comfort and gender: A literature review. Indoor Air 2011, 22, 96-109. [CrossRef]

123. Yi, C.C. Urban housing satisfaction in a transitional society: A case study in Taichung, Taiwan. Urban. Stud. 1985, 22, 1-12. [CrossRef]

124. Ren, H.; Folmer, H. Determinants of residential satisfaction in urban China: A multi-group structural equation analysis. Urban Stud. 2016, 54, 1407-1425. [CrossRef]

125. Baiden, P.; Arku, G.; Luginaah, I.; Asiedu, A.B. An assessment of residents' housing satisfaction and coping in Accra, Ghana. J. Public Health 2011, 19, 29-37. [CrossRef]

126. Liu, D.; Crull, S.R. Housing satisfaction of Asian and Pacific Islander households in the United States. Hous. Soc. 2006, 33, 21-38. [CrossRef]

127. Mohit, M.A.; Ibrahim, M.; Rashid, Y.R. Assessment of residential satisfaction in newly designed public low-cost housing in Kuala Lumpur, Malaysia. Habitat Int. 2010, 34, 18-27. [CrossRef]

128. Rohe, W.M.; Basolo, V. Long-term effects of homeownership on the self-perceptions and social interaction of low-income persons. Environ. Behav. 1997, 29, 793-819. [CrossRef]

129. Wu, W.; Stephens, M.; Du, M.; Wang, B. Homeownership, family composition and subjective wellbeing. Cities 2019, 84, 46-55. [CrossRef]

130. Addo, I.A. Assessing residential satisfaction among low income households in multi-habited dwellings in selected low income communities in Accra. Urban. Stud. 2015, 53, 631-650. [CrossRef]

131. Baillie, S. Dwelling features as intervening variables in housing satisfaction and propensity to move. Hous. Soc. 1990, 17, 1-15. [CrossRef]

132. Galster, G. Identifying the correlates of dwelling satisfaction an empirical critique. Environ. Behav. 1987, 19, 539-568. [CrossRef]

133. Ukoha, O.M.; Beamish, J.O. Assessment of residents' satisfaction with public housing in Abuja, Nigeria. Habitat Int. 1997, 21, 445-460. [CrossRef]

134. Peck, C.; Kay Stewart, K. Satisfaction with housing and quality of life. Home Econ. Res. J. 1985, 13, 363-372. [CrossRef]

135. Onibokun, A.G. Social system correlates of residential satisfaction. Environ. Behav. 1976, 8, 323. [CrossRef]

136. Individual Database, Household Budget 2018; Statistics Poland: Warsaw, Poland, 2019; unpublished data.

137. Charlier, D.; Legendre, B. A multidimensional approach to measuring fuel poverty. Energy J. 2019, 40, 27-54. [CrossRef]

138. Heindl, P. Measuring fuel poverty: General considerations and application to German household data. FinanzArchiv/Public Financ. Anal. 2015, 71, 178-215. [CrossRef]

139. Tait, L. Towards a multidimensional framework for measuring household energy access: Application to South Africa. Energy Sustain. Dev. 2017, 38, 1-9. [CrossRef]

140. Sareen, S.; Thomson, H.; Tirado Herrero, S.; Gouveia, J.P.; Lippert, I.; Lis, A. European energy poverty metrics: Scales, prospects and limits. Glob. Transit. 2020, 2, 26-36. [CrossRef]

141. Meyer, S.; Laurence, H.; Bart, D.; Lucie, M.; Kevin, M. Capturing the multifaceted nature of energy poverty: Lessons from Belgium. Energy Res. Soc. Sci. 2018, 40, 273-283. [CrossRef]

142. Herrero, S.T. Energy poverty indicators: A critical review of methods. Indoor Built Environ. 2017, 26, 1018-1031. [CrossRef]

143. Thomson, H.; Bouzarovski, S.; Snell, C. Rethinking the measurement of energy poverty in Europe: A critical analysis of indicators and data. Indoor Built Environ. 2017, 26, 879-901. [CrossRef]

144. Kelly, J.A.; Clinch, J.P.; Kelleher, L.; Shahab, S. Enabling a just transition: A composite indicator for assessing home-heating energy-poverty risk and the impact of environmental policy measures. Energy Policy 2020, 146, 111791. [CrossRef]

145. Kaufman, L.; Rousseeuw, P.J. Finding Groups in Data: An Introduction to Cluster Analysis; John Wiley \& Sons: Hoboken, NJ, USA, 2009.

146. Kassambara, A. Practical Guide to Cluster Analysis in R: Unsupervised Machine Learning; STHDA, 2017 ; Volume 1. 
147. Na, S.; Xumin, L.; Yong, G. Research on k-means clustering algorithm: An improved k-means clustering algorithm. In Proceedings of the Third International Symposium on Intelligent Information Technology and Security Informatics, Jian, China, 2-4 April 2010.

148. Borlea, I.D.; Precup, R.E.; Dragan, F.; Borlea, A.B. Centroid update approach to K-means clustering. Adv. Electr. Comput. Eng. 2017, 17, 3-10. [CrossRef]

149. Khanmohammadi, S.; Naiier, A.; Samaneh, S. An improved overlapping k-means clustering method for medical applications. Expert Syst. Appl. 2017, 67, 12-18. [CrossRef]

150. Windarto, A.P. Implementation of data mining on rice imports by major country of origin using algorithm using k-means clustering method. Int. J. Artif. Intell. Res. 2017, 1, 26-33. [CrossRef]

151. Melchers, R.E.; Beck, A.T. Structural Reliability Analysis and Prediction; John Wiley \& Sons: West Sussex, UK, 2018.

152. Fabbri, K. The role of building in the reduction of fuel poverty. In Urban Fuel Poverty; Elsevier: Amsterdam, The Netherlands, 2019; pp. 63-103. [CrossRef]

153. Atanasiu, B.; Kontonasiou, E.; Mariottini, F. Alleviating fuel poverty in the EU: Investing in home renovation, a sustainable and inclusive solution. BPIE Build. Perform. Inst. Eur. 2014, 56.

154. Gaspari, J. Cities and buildings efficiency improvement of energy-poor household. In Urban Fuel Poverty; Elsevier: Amsterdam, The Netherlands, 2019; pp. 211-238. [CrossRef]

155. Acharya, R.H.; Sadath, A.C. Energy poverty and economic development: Household-level evidence from India. Energy Build. 2019, 183, 785-791. [CrossRef]

156. Aristondo, O.; Onaindia, E. Counting energy poverty in Spain between 2004 and 2015. Energy Policy 2018, 113, 420-429. [CrossRef]

157. Giamalaki, M.; Kolokotsa, D. Understanding the thermal experience of elderly people in their residences: Study on thermal comfort and adaptive behaviors of senior citizens in Crete, Greece. Energy Build. 2019, 185, 76-87. [CrossRef]

158. Lusardi, A.; Mitchell, O.S.; Oggero, N. The changing face of debt and financial fragility at older ages. AEA Pap. Proc. 2018, 108, 407-411. [CrossRef]

159. Sánchez, C.S.G.; Fernández, A.S.; Peiró, M.N. Feminisation of energy poverty in the city of Madrid. Energy Build. 2020, 223, 110157. [CrossRef]

160. Díaz, J.; López, I.A.; Carmona, R.; Mirón, I.J.; Luna, M.Y.; Linares, C. Short-term effect of heat waves on hospital admissions in Madrid: Analysis by gender and comparision with previous findings. Environ. Pollut. 2018, 243, 1648-1656. [CrossRef]

161. Romanach, L.; Hall, N.; Meikle, S. Energy consumption in an ageing population: Exploring energy use and behaviour of low-income older Australians. Energy Procedia 2017, 121, 246-253. [CrossRef]

162. Sadath, A.C.; Acharya, R.H. Assessing the extent and intensity of energy poverty using Multidimensional Energy Poverty Index: Empirical evidence from households in India. Energy Policy 2017, 102, 540-550. [CrossRef]

163. Miller, W.; Vine, D.; Amin, Z. Energy efficiency of housing for older citizens: Does it matter? Energy Policy 2017, 101, 216-224. [CrossRef]

164. Ahmed, A.; Gasparatos, A. Multi-dimensional energy poverty patterns around industrial crop projects in Ghana: Enhancing the energy poverty alleviation potential of rural development strategies. Energy Policy 2020, 137, 111123. [CrossRef]

165. Sharma, S.V.; Han, P.; Sharma, V.K. Socio-economic determinants of energy poverty amongst Indian households: A case study of Mumbai. Energy Policy 2019, 132, 1184-1190. [CrossRef]

166. Frank, D.A.; Neault, N.B.; Skalicky, A.; Cook, J.T.; Wilson, J.D.; Levenson, S.; Meyers, A.F.; Heeren, T.; Cutts, D.B.; Casey, P.H.; et al. Heat or eat: The Low Income Home Energy Assistance Program and nutritional and health risks among children less than 3 years of age. Pediatrics 2006, 118, 1293-1302. [CrossRef]

167. Beatty, T.; Blow, L.; Crossley, T. Is there a 'heat-or-eat' trade-off in the UK? J. R. Stat. Soc. Ser. A (Stat. Soc.) 2014, 177, 281-294. [CrossRef]

168. Hills, J. Getting the Measure of Fuel Poverty. Final Report of the Fuel Poverty Review; Centre for Analysis of Social Exclusion, London School of Economics and Political Science: London, UK, 2012.

169. Thomson, H.; Snell, C.; Liddell, C. Fuel poverty in the European Union: A concept in need of definition? People Place Policy Online 2016, 10, 5-24. [CrossRef]

170. Clancy, J.S.; Daskalova, V.I.; Feenstra, M.H.; Franceschelli, N. Gender Perspective on Access to Energy in the EU; Publications Office of the European Union: Brussels, Belgium, 2017. [CrossRef]

171. Jacques-Aviñó, C.; Dvorzak, J.L.; Marí-Dell'Olmo, M.; Arjona, D.R.; Peralta, A.; Carrere, J.; Benach, J.; Ramos, C.; Plana, M.; López, M.J. Evaluación cualitativa de una intervención para reducir la pobreza energética. Rev. Saúde Pública 2019, 53, 62. [CrossRef]

172. Moniruzzaman, M.; Day, R. Gendered energy poverty and energy justice in rural Bangladesh. Energy Policy 2020, $144,111554$. [CrossRef]

173. Llorca, M.; Rodriguez-Alvarez, A.; Jamasb, T. Objective vs. subjective fuel poverty and self-assessed health. Energy Econ. 2020, 87, 104736. [CrossRef]

174. Sokołowski, J.; Frankowski, J. How to Improve the Quality of Life of Energy Poor People? IBS Policy Paper: Warsaw, Poland, 2021; (Jak poprawić jakość życia osób ubogich energetycznie? Seria IBS Policy Paper, no. 1, Warszawa). (In Polish) 
175. Piekut, M.; Piekut, K. Energy sources in households from Poland and Ukraine compared to other European countries. (Źródła energii w gospodarstwach domowych z Polski i Ukrainy na tle innych krajów europejskich). In Selected Issues of Socio-Economic Development in Poland and Ukraine; Piekut, M., Smetyna, N., Eds.; Warsaw University of Technology: Warsaw, Poland, 2020. (In Polish)

176. Benjamin, G.C.; Vernon, T.M. National Healthy Housing Standard. National Center for Healthy Housing. APHA. 2014. Available online: https://nchh.org/resource-library/national-healthy-housing-standard.pdf (accessed on 30 August 2021).

177. Schieweck, A.; Uhde, E.; Salthammer, T.; Salthammer, L.C.; Morawska, L.; Mazaheri, M.; Kumar, P. Smart homes and the control of indoor air quality. Renew. Sustain. Energy Rev. 2018, 94, 705-718. [CrossRef]

178. Piekut, M. The Consumption of Renewable Energy Sources (RES) by the European Union Households between 2004 and 2019. Energies 2021, 14, 5560. [CrossRef] 